\title{
Lessons on Marine Protected Area Management in Northern Boreal Regions from the United States and Norway
}

\author{
SUSANNE F. MCDERMOTT, LENE BUHL-MORTENSEN, GEIR DAHLE, DEBORAH HART, \\ ALAN C. HAYNIE, TORE JOHANNESSEN, ERLEND MOKSNESS, ESBEN MOLAND OLSEN, \\ ERIK OLSEN, JOHN V. OLSON, PAUL D. SPENCER, and WILLIAM STOCKHAUSEN
}

\section{Introduction}

Marine protected areas (MPA's) can be considered a tool for ecosystembased marine spatial planning (Katsanevakis et al., 2011; Stelzenmüller et al., 2013) and have been established to meet the goals of biodiversity conservation, sustainable management of marine resources, and marine heritage preservation (Fernandez and Castilla, 2005; Field et al., 2006; Worm et al., 2006; Greenville and Macaulay, 2007;

Susanne F. McDermott, Alan C. Haynie, William Stockhausen, and Paul D. Spencer are with the Alaska Fisheries Science Center, National Marine Fisheries Service, NOAA, 7600 Sandpoint Way NE, Seattle, WA 98115-6349. Erlend Moksness, Erik Olsen, Lene Buhl-Mortenesen, Esben Morland Olsen, Geir Dahl, and Tore Johannessen are with the Institute of Marine Research, P.O. Box 1870 Nordnes, 5817 Bergen, Norway. Deborah Hart is with the Northeast Fisheries Science Center, National Marine Fisheries Service, 166 Water Street, Woods Hole, MA 02543-1026. John V. Olsen is with the Alaska Regional Office, National Marine Fisheries Service, P.O. Box 43, 222 West 7th Ave, Anchorage, AK 99513-7577. Corresponding author: Susanne F. McDermott, Susanne.mcdermott@ noaa.gov

doi: https://doi.org/10.7755/MFR.79.1.2
Gleason et al., 2010; Grafton et al., 2011; Hansen et al., 2011; Rice et al., 2012). MPA's can also serve to protect habitats from destructive fishing practices (e.g., protection against fishing impacts on coral reefs off Norway), extraction activities, energy production, and petroleum development.

The use of MPA's has necessitated the creation of organizations to monitor and give advice on their designation and use, both within nations (i.e., the National Marine Protected Area Center (NMPAC), part of the National Oceanic and Atmospheric Administration (NOAA) in the United States), and internationally (i.e., the Food and Agricultural Organization (FAO) of the United Nations) (Murawski et al., 2000). For the purposes of this paper, we use the MPA definition formulated in the United States: ". . . area of the marine environment that has been reserved ... . to provide lasting protection for part or all of the natural and cultural resources therein." 1

From the perspective of many consumptive users of the ecosystem (e.g.,

$\overline{{ }^{1} \mathrm{http}: / / m a r i n e p r o t e c t e d a r e a s . n o a a . g o v . ~}$ fishermen, shipping industry, oil industry), MPA's are often seen as a means to exclude users from accessing valuable areas (Katsanevakis et al., 2011; Thorpe et al., 2011; Abbott and Haynie, 2012; Buhl-Mortensen et al., 2017). Therefore, the decisions regarding area closures are often highly controversial (Thorpe et al., 2011; Rice et al., 2012; Fenner, 2016), and motivate examination of the effectiveness of MPA's relative to other management tools (i.e., reduction in catch levels or fishing effort for sustainably managing fisheries yield).

Within the scientific community, there is ongoing research on the effectiveness of MPA's as management tools for fish species and ecosystems (Trexler and Travis, 2000; Roberts et al., 2005; Sanchirico et al., 2006; Worm et al., 2006; Lester et al., 2009; Sorensen and Thomsen, 2009; Thorpe et al., 2011). Establishment of MPA's may not consider the potential interactions with other spatial closures, physical and biological processes such as ocean currents and phenology, and diverse human uses and responses to the MPA (Katsanevakis et al., 2011).
ABSTRACT-In comparison to tropical reef systems, relatively few marine protected areas (MPA's) exist in temperate or subarctic systems (e.g., North Pacific and North Atlantic) where species diversity is lower, abundance of individual species is often higher, and many fish species exhibit large amounts of movement during one or more of their life stages, especially as adults. A review of MPA's in three northern areas-the Northwest Atlantic, Northeast Atlantic, and the Northeast Pacific - indicates that MPA's can be useful management tools towards fisheries management and habitat conservation. However, achieving fishery goals, such as sustainable use of the fisheries resources, will depend on population abundance (relative to unfished conditions) and fish behavior and movement. For example, depleted populations of stationary species such as Atlantic sea scallops, Placopecten magellanicus, in the Northeast Atlantic and European lobster, Homarus grammarus, in the North Sea have responded positively to small MPA's, whereas migratory offshore Atlantic cod, Gadus morhua, and Pacific cod, Gadus microcephalus, apparently do not appear to benefit from closed areas because of movement into fished areas. Efficient habitat conservation requires detailed habitat mapping on relevant spatial scales. In northern boreal systems with large remote areas, this information is difficult and expensive to access. An alternative strategy of closing and protecting unexploited areas has worked well for the Aleutian Island coral closure area in Alaska. MPA's can be effective fisheries management tools when the species to be protected have been depleted and show a small to moderate level of movement, and reproductive success is ensured. MPA's can be effective at preserving habitat when the design is based on scientific information and takes into account the impact on the user groups. 
For example, an MPA may be created for a single species without consideration of the impact on other species in and out of the MPA (Martell et al., 2005). In other cases, the potential interactions between closed areas for a single fish stock and other fisheries or user groups are ignored if they are outside of the management system. Comparing different MPA types and outcome scenarios in a larger context can help us determine when MPA's are the best solution and when other management strategies might be more effective.

While much of the scientific literature and political discussion has focused on the use of marine protection of tropical ecosystems as related to coral reefs and mangroves, this paper aims to expand the scientific discussion on the use of MPA's as an important element in managing temperate, boreal, and Arctic marine ecosystems (Murawski et al., 2000, Witherell and Woodby, 2005, Fenberg et al., 2012). The number of studies on MPA's has increased over the last 15 years with 5,901 papers published with "Marine Protected Area" in the title, abstract, or keywords since 1991.2 However, only 306 of these papers (7\%) addressed MPA's in northern regions with temperate ocean ecosystems. Area closures as protection measures for habitat preservation, bycatch avoidance, or effort reduction have been used as management tools for decades for a variety of fish and shellfish stocks, marine mammal populations, and seabird colonies in northern temperate regions. However, few such closures were termed "Marine Protected Areas" when they were created, even though under recent definitions by FAO and NOAA they would be identified as such (Witherell and Woodby, 2005).

There are several challenges when designing MPA's in northern ecosystems. First the productivity of these systems is often dominated by a few species of high abundance which tend to occur in areas of high biological

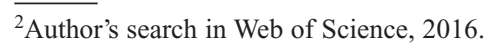

production (Rohde, 1992; Gray, 2001), such as Atlantic cod, Gadus morhua, in Norway, walleye pollock, Gadus chalcogrammus, and yellowfin sole, $L i-$ manda aspera, in the Bering sea, and haddock, Melanogrammus aeglefinus, on Georges Bank (Gray, 1997). The areas of high biological production can vary seasonally and spatially between years, and fish species can undergo large scale seasonal migrations between feeding and spawning grounds (Shimada and Kimura, 1994; Bailey et al., 1997; Comeau et al., 2002; Olsen et al., 2010). It is therefore difficult to establish MPA's for these species that encompass their home range throughout their life cycles, particularly for MPA's that may be in place for specific seasons within a year.

The second challenge is that often the size and remoteness of the areas to be protected hinders data collection. Because the management areas defined for these northern ecosystems are often large with low human population and infrastructure along the coast, we often lack detailed knowledge of the spatial distribution of vulnerable and/ or productive bottom habitats such as cold-water coral reefs. This challenge has been addressed in Norway by the seafloor mapping program MAREANO (Marine Areal Database for Norwegian Waters: www.mareano.no) that uses multibeam hydroacoustic technology and underwater camera habitat classification (Buhl-Mortensen et al., 2015). In Canada, the distribution of corals on the western Atlantic coast was identified to prevent damage by the fisheries and petroleum industries (Mortensen et al., 2005; Mortensen et al., 2006). However, such programs are resource- and time-intensive.

Finally, some northern countries, such as the United States and Norway, have sophisticated fisheries management systems that require a lengthy process in order to either implement or adjust MPA's, often involving stakeholder input and complicated legislative and regulatory procedures that can affect the ability to rapidly make management adjustments in these systems. The complicated management struc- ture emphasizes the need to incorporate flexibility into the management process (to the extent possible). Moreover, the issues of spatial and temporal variation in productivity and limited spatial information illustrate the importance of assessing whether MPA's are expected to be the most appropriate management tool.

Our objective in this paper is to review and evaluate the effectiveness of MPA's in Northeast Atlantic (Norwegian), Northeast Pacific (U.S.), and Northwest Atlantic (U.S.) waters (Fig. 1). All three systems have sophisticated fisheries management plans in place that manage fish stocks based on single-species stock assessments, and they allocate total allowable catch (TAC) based on sustainable harvest levels. In addition, in all three systems, area closures have been part of the fisheries management process but were often not designed as part of a comprehensive network of MPA's.

To evaluate the effectiveness, we focus on MPA's with measurable indicators, such as biomass trends from stock assessments or fish or invertebrate densities from scientific surveys. We provide a short overview of each ecosystem, a narrative history as to how the protection measures came into place, and a description of the MPA's goals and objectives. We then examine if those goals have been met and any other effects that occurred as a result of the closures.

Several of the MPA's considered here have been in place for many years, allowing us to analyze their effectiveness in achieving the goals and objectives over the long term. Others, such as the ones in the Lofoten Islands area and for Atlantic cod, are relatively new and will be discussed with respect to design and implementation strategies (Olsen et al., 2007; BuhlMortensen, 2017). We arrange our case studies by ecosystem and discuss the MPA's with respect to conservation versus fisheries management goals.

The goal of MPA's for fisheries management is to increase sustainable yields, but this may come with shortand long-term economic costs. Bio- 
mass would increase within the MPA provided that the stock had been fished down below its virgin biomass, and the MPA is larger than the typical scale of fish movement, with stronger responses expected for heavily fished sedentary species. In most circumstances (in particular, if the stock-recruit relationship is always increasing), biomass within the closures cannot increase on average higher than virgin level (assuming unchanged carrying capacity for the stock). Thus, much larger increases inside the closures can theoretically occur for heavily fished stocks than for those that are lightly fished, given similar carrying capacity of the ecosystem as during the time of the virgin biomass.

Secondly, the magnitude of the response also depends on adult mobility. Highly mobile species will leave the closures, and thus it is hard to monitor positive effects on the population. Species of moderate mobility may increase in abundance if at least a portion of the fish remain within the closure, but the population increase will likely be less than that of stationary species because some migration of individuals from the closures to the fished areas will occur.

However, in order to increase yield, there needs to be sufficient "spillover" of larvae and/or adults from the MPA into the fished areas that is greater than the direct loss of yield owing to the MPA (Hart, 2006), and insufficient spillover may not produce a net economic benefit to the fishery (Sanchirico et al., 2006; Gaines et al., 2010). Closing important fishing grounds may lead to a spatial reallocation of effort into a smaller area as well as the loss of yield from fish that remain inside the MPA.

Such shifts in effort can be costly to the fishing industry, because fishing vessels may need to travel further and to areas that may have lower average catch rates or product value (Smith and Wilen, 2003; Haynie and Layton, 2010). Additionally, the redistribution of fishing effort can increase the bycatch of non-target fish species or increase the habitat impact in areas previously not heavily fished. Therefore, it is important to monitor the economic impact of MPA's as well as the biological impact on the ecosystem.

Finally, our goal in examining an MPA system is to identify how it addresses the overarching (and sometimes conflicting) strategic spatial management objectives of conservation and use (Rice and Houston, 2011) and the associated trade-offs and costs. For example, one such tradeoff is between the long-term goals of habitat protection and yield increase and the short-term loss of fisheries.

\section{Ecosystem Descriptions}

\section{Norway Northeast Atlantic}

\section{The Barents Sea and the Lofoten Islands}

The Barents Sea (Fig. 1-3) is a subarctic continental shelf ecosystem (average depth $230 \mathrm{~m}$ ) bordered in the west by the edge of the continental shelf towards the Norwegian Sea, in the east by Novaya Zemlya, and in the north by the Arctic Ocean (Svalbard archipelago). The convergence of warm Atlantic and cold Arctic waters creates a productive ecosystem that supports high densities of fish, crustaceans, seabirds, and marine mammals (Sundby and Nakken, 2008).

The most important commercially fished species in the Barents Sea are Atlantic cod; haddock; capelin, Mallotus villosus; saithe, Pollachius virens; and herring, Clupea harengus. Herring reside in the Barents Sea only as juveniles while living as adults in the Norwegian Sea and spawning further south along the Norwegian coast. The other four species use the Barents Sea throughout their life history, spawning along the Norwegian coast and drifting into the Barents Sea with the currents during the larval stage (Olsen et al., 2010). The large stocks of pelagic and demersal fish sustain a large fishery from Norway and Russia and a small fleet from the European Union. All fish stocks except saithe are jointly managed between Norway and Russia through the Russian-Norwegian Fisheries Commission.
In the Lofoten Islands area (Fig. 2, $3,4)$, the Norwegian continental shelf is at its narrowest and is dominated by shallow banks and deep troughs. Upwelling along the steep continental slope results in high primary and secondary productivity, a large fish biomass, and highly productive fisheries (Sundby and Nakken, 2008). In the transition layer between the cold Norwegian Coastal Current and the warmer, nutrient-rich Atlantic Current lie the spawning grounds of the Atlantic cod. The combination of high plankton production and large eddies off the Lofoten Islands make this area ideal for larval feeding and retention during the first life stages of Atlantic cod (Sundby and Nakken, 2008). In this area, the mapping activity of MAREANO has revealed hundreds of coral reefs and other vulnerable marine ecosystems (VME's) and trawl marks resulting from the high fishing intensity are common (Fig. 3a, 3b).

\section{The North Sea and} the Skagerrak Area

The North Sea (Fig. 2, 5) is a shallow sea bounded by the British Isles, continental Europe, and Norway with an average depth of $\sim 100 \mathrm{~m}$ (OSPAR, 2000). The North Sea connects to the North Atlantic through the English Channel in the south and the Norwegian Sea in the north. Most of the water masses enter from the northwest, where part of the North Atlantic Drift Current branches off into the North Sea, mixes with different water masses and exits as the Norwegian Coastal Current further north. The North Sea fisheries have been heavily exploited by the surrounding densely populated and industrialized countries. Over the last four decades the offshore oil and gas industry in the region has become very economically important. Environmental concerns include overfishing, runoff from industry and agriculture, oil spills, dredging and dumping, and, in recent years, increasing water temperature.

The continental shelf off the Norwegian Skagerrak coast is narrow and the slope extends down to about 700 


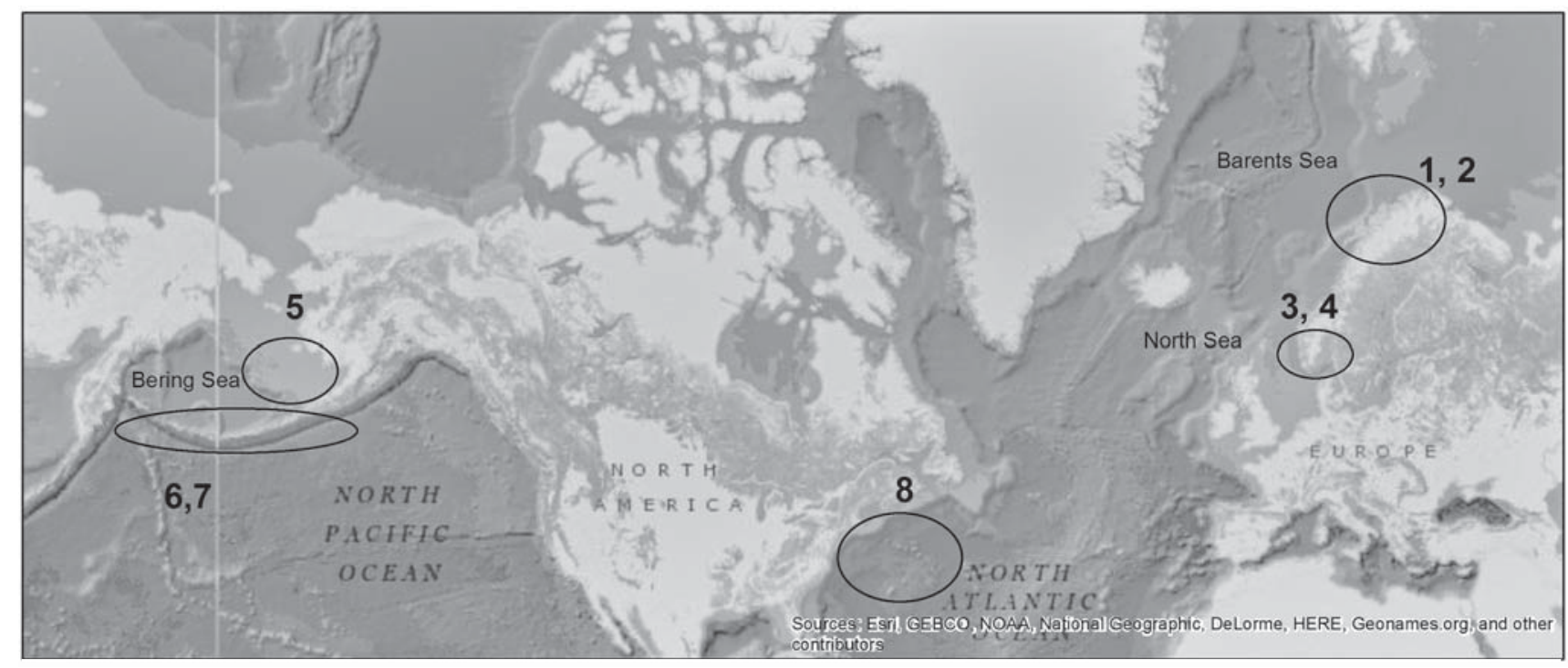

Figure 1.-MPA study areas: $1=$ Barents Sea vulnerable and valuable habitat, $2=$ Lofoten Island Atlantic cod closures, $3=$ North Sea sandeel fisheries closures, 4=Skagerrak Lobster reserves, 5= Bering sea crab closures, $6=$ Aleutian Island coral protection area, $7=-$ Steller sea lion trawl exclusion zones, $8=$ Georges Bank fishery closures.

$\mathrm{m}$ in the Norwegian Trench (Fig. 2, 6). Except for Denmark, the Skagerrak coastline is complex with numerous smaller fjords and archipelagos, a narrow shelf, and a steep slope. This sets the stage for resident and locally adapted populations of fish (Rogers et al., 2014). Among the commercially exploited species are Atlantic cod; Spanish mackerel, Scomber scombrus; European lobster, Homarus gammarus; and northern prawn, Pandalus borealis. Other species, such as the anadromous brown trout, Salmo trutta; and pollack, Pollachius pollachius, are often targeted by recreational fishermen. The fish communities along the Skagerrak coast also include several flatfishes (Pleuronectidae), labrids (Labridae), clupeids (Clupeidae), gobies (Gobiidae) and other smaller non-harvested species (Barcelo et al., 2016).

\section{U.S. Northeast Pacific}

\section{Eastern Bering Sea}

The eastern Bering Sea (Fig. 7) is a diverse subarctic ecosystem that supports some of the world's largest commercial fisheries. The eastern Bering Sea is broadly defined as the area bor- dered by the Bering Strait to the north, the International Dateline to the west, the Aleutian Archipelago and Alaska Peninsula to the south, and the Alaska mainland to the east. The continental shelf is shallow (less than $200 \mathrm{~m}$ ) and broad (500-800 km), gradually increasing in depth from the Alaska coast to $180 \mathrm{~m}$ at the edge of the continental shelf, with an average depth of $70 \mathrm{~m}$ (Hunt and Megrey, 2005) and ending in the abyssal Aleutian Basin in the southwest. It is generally featureless, with the exception of three large and several small islands (NRC, 1996). There are seven large canyons along the slope area of the Bering Sea shelf which are highly productive areas that support spawning and feeding fish and shellfish.

Fisheries in the eastern Bering Sea target many groundfish species that include walleye pollock; yellowfin sole; northern rock sole, Lepidopsetta polyxystra; flathead sole, Hippoglossoides elassodon; and Pacific cod. Walleye pollock is one of the world's largest commercial fisheries and yellowfin sole is one of the world's largest flatfish fisheries. Pollock replaced yellowfin sole in the mid-1960's as the principal exploited groundfish species. The annual TAC of all groundfish in the eastern Bering Sea and Aleutian Island fisheries is capped at 2 million $t$.

Major fisheries also target (or targeted) crab species such as red and blue king crab, Paralithodes camtschaticus and $P$. platypus, respectively; snow crab, Chionoecetes opilio; and Tanner crab, C. bairdi. While not as large in terms of landings as the groundfish fisheries, the crab fisheries are very valuable. Each crab stock has undergone dramatic boom and bust cycles over the past several decades, and the various fisheries have been closed at one time or another due to overfishing concerns (NPFMC, 2011a).

Yellowfin sole was the first groundfish species targeted by the eastern Bering Sea commercial fisheries during the late 1960 's, while other species were only taken as bycatch (NPFMC, 2011b). Following a decline in abundance of yellowfin sole, other species (principally pollock) were targeted, and total catches peaked at 2.2 million $\mathrm{t}$ in 1972. Pollock is now the principal fishery, with catches peaking at approximately $1.3-1.5$ million $t$ in years of high recruitment (NPFMC, 2011b). 


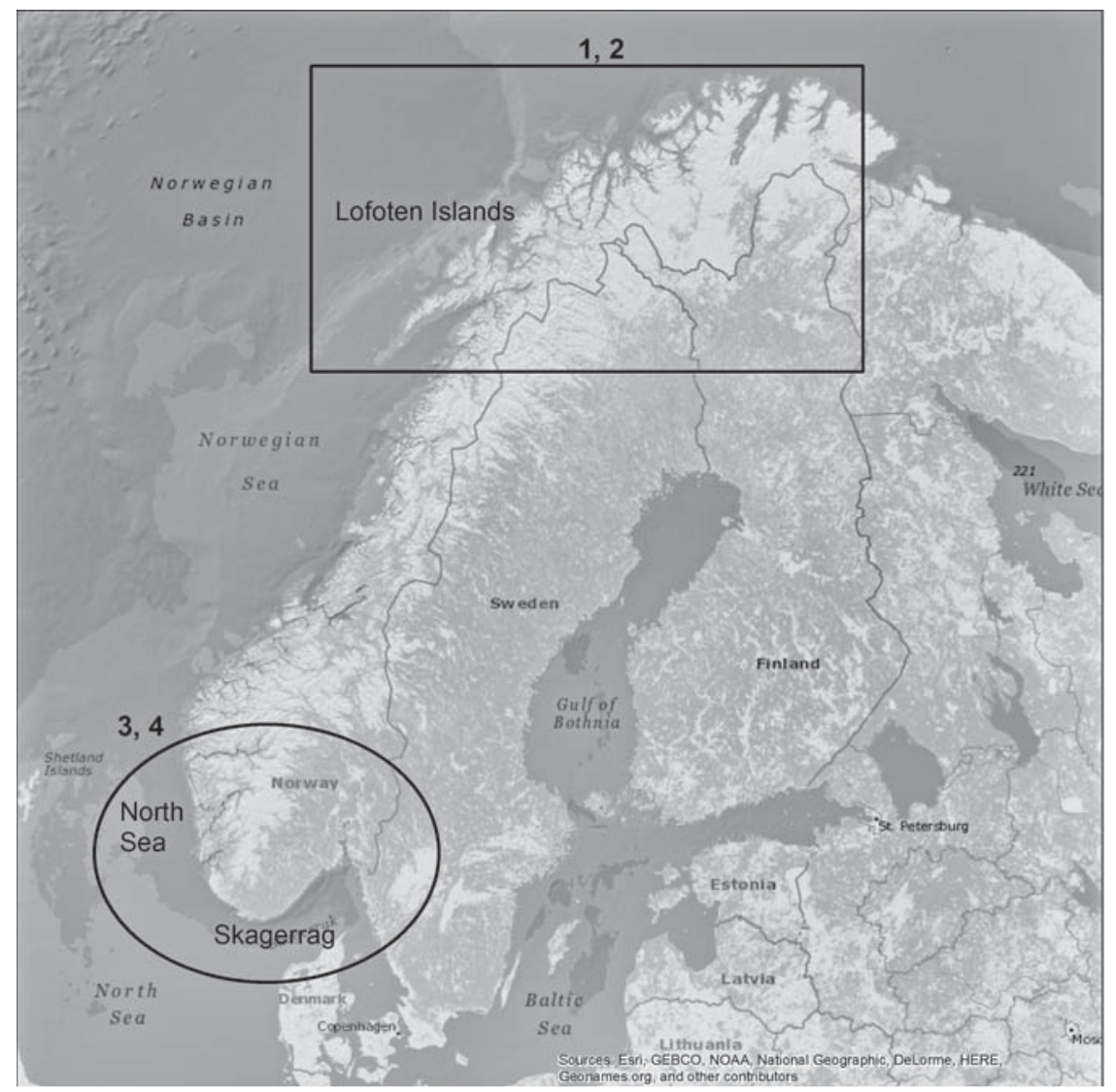

Figure 2.- Study areas in Norwegian waters: $1=$ Barents Sea vulnerable and valuable habitat, $2=$ Lofoten Island Atlantic cod closures, $3=$ North Sea sandeel fisheries closures, 4=Skagerrak Lobster reserves.

After the Magnuson-Stevens Fishery Conservation and Management Act (MSFCMA) was adopted in 1976, catch restrictions and other management measures were placed on the fishery, and total groundfish catches have since varied from 1 to 2 million t. Total groundfish catches have been below the 2 million $t$ cap. Catches in the eastern Bering Sea and Aleutian Islands for 2016 totaled approximately 1,953,000 t (NPFMC, 2016).

\section{Aleutian Islands}

The Aleutian-Commander Islands archipelago extends more than 3,000 $\mathrm{km}$ between Alaska and Russia, and forms the southern border of the Bering Sea. The islands are mostly peaks of steep volcanoes surrounded by narrow and steep continental shelves. eign countries were allocated catch quotas in order to develop the U.S. domestic industry by sharing knowledge about fishing locations and operations, resulting in a joint venture period from 1977 to 1990. Since 1990, the fleet has been entirely domestic (NPFMC, 2016).

Total catches were in excess of $150,000 \mathrm{t}$ throughout the following decade. But in 1999, the pollock fishery was severely restricted due to concerns regarding the fishery's impact on Steller sea lions, Eumetopias jubatus. Since then, total groundfish catches have averaged slightly above 100,000 $\mathrm{t}$ and are typically about $50 \%$ Atka mackerel, 30\% Pacific cod, 15\% Pacific ocean perch, and 5\% other species (Zador, 2014).

\section{U.S. Northwest Atlantic}

\section{Georges Bank}

Georges Bank is a submerged plateau located east of Massachusetts and southwest of Nova Scotia (Backus, 1987). It measures about $300 \mathrm{~km} \times 150$ $\mathrm{km}$ (ca. 45,000 km²); depths are less than $100 \mathrm{~m}$ on most of the bank, and are less than $10 \mathrm{~m}$ on the shoals in its north-central portion. Because of its high primary productivity and retentive gyre, Georges Bank is one of the most productive fishing grounds in the world (Cohen and Grosslein, 1987).

Commercial fisheries began on Georges Bank in the 18th century, but by the end of the 19th century, overfishing of Atlantic halibut, Hippoglossus hippoglossus; Atlantic cod; and large whales was already evident (Hennemuth and Rockwell, 1987; Clapham and Link, 2006). Exploitation of many fisheries reached very high levels in the 1960's and early 1970 's, much of it due to foreign factory trawler vessels (Hennemuth and Rockwell, 1987; Fogarty and Murawski, 1998; Overholtz, 2002; Hart and Rago, 2006). When foreign fishing vessels were excluded by the declarations of 200-nmi EEZ by the United States and Canada in 1976, effort in the domestic groundfish and sea scallop fisheries increased, resulting 


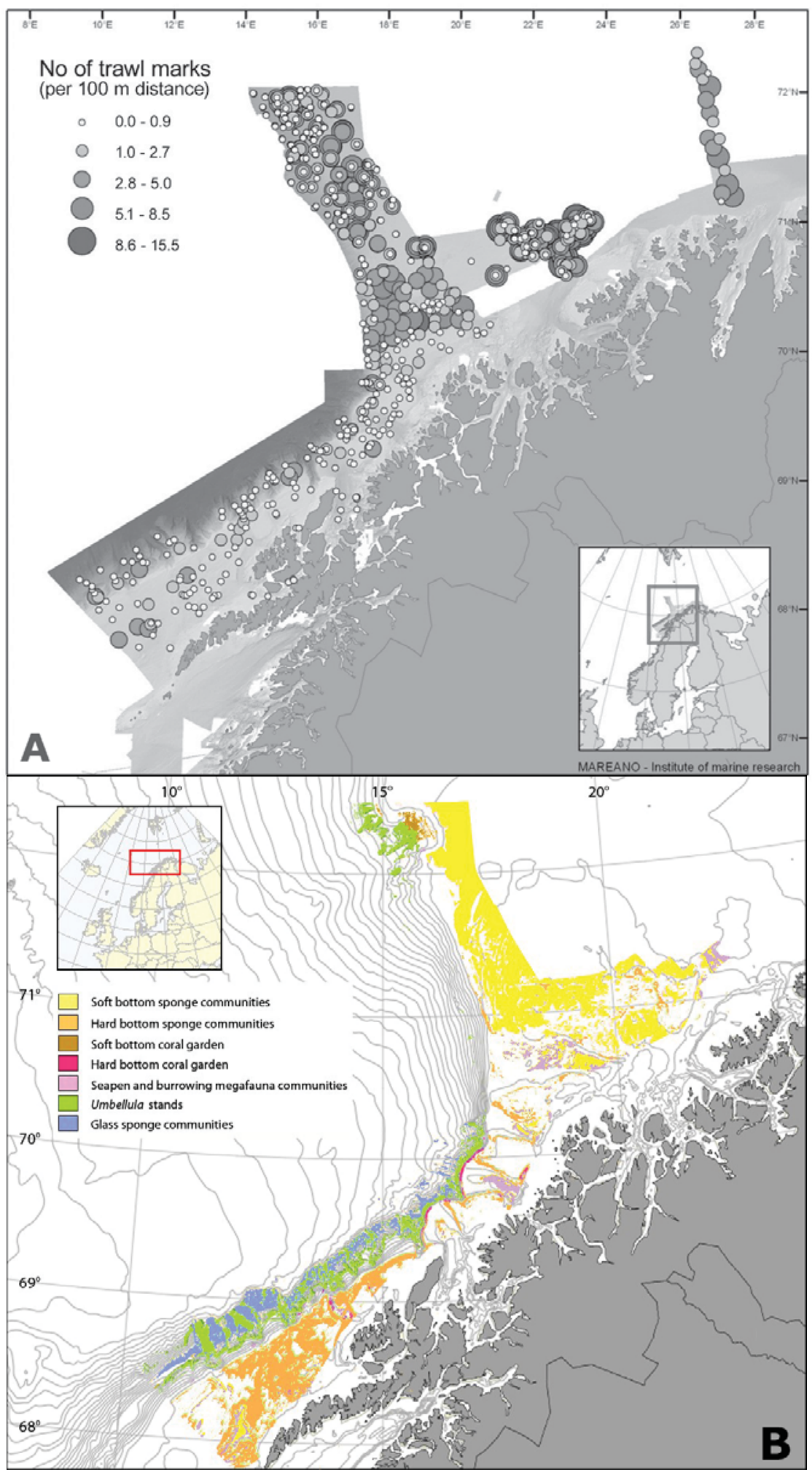

Figure 3.-A) Abundance of trawlmarks (observed no/100 $\mathrm{m}$ seafloor) in the Lofoten Vesterålen area (Buhl-Mortensen et al., 2016). B) Distribution of vulnerable habitats in the area mapped by MAREANO (Buhl-Mortensen et al., 2015). in a collapse in the landings and biomasses of these fisheries in the early 1990's (Fogarty and Murawski, 1998; Hart and Rago, 2006).

\section{MPA Case Study Evaluations}

\section{Northeast Atlantic (Norwegian waters)}

The establishment of MPA's in Norway has followed multiple paths. However, one common denominator is the 2002 Johannesburg Declaration that initiated the process for sustainable use and ecosystem-based management (EBM) of all living marine resources (United-Nations, 2002). This declaration, together with the Convention on Biological Diversity (CBD), scientific publications (Fernandez et al., 2005; Crowder et al., 2006), and position documents from non-government organizations (NGO's) (Kelleher, 1999; FAO, 2011), has created strong international pressure for implementing marine protection measures.

Establishing ecosystem-based management has led to calls for various forms of integrated management of marine areas, with marine spatial planning (MSP) being the most developed and comprehensive approach (Douvere, 2008). A central part of MSP is the establishment of zoning plans, where MPA's are one of the zoning measures that can be used.

At the start of the century, the Norwegian government initiated a process aimed at managing marine space in its marine ecosystem through regional management plans (Barents Sea, BSMP), Norwegian Sea, and North Sea (Olsen et al., 2007; Ottersen et al., 2011; Olsen et al., 2016) balancing human uses and conservation requirements. In parallel, a process to design a representative network of MPA's in the Norwegian EEZ as part of an integrated management plan was initiated and a preliminary network of MPA's was recommended in 2003. So far only a few of the MPA's proposed in 2003 have been established, but the process is ongoing.

However, Norwegian fisheries management includes the extensive use of 
closed areas to protect juvenile fish or reduce bycatch, banning trawling from all areas closer than $4 \mathrm{nmi}$ from the coast, and other measures that are de-facto area-based protection; these management measures are seasonal MPA's. In addition all deepwater Lophelia coral reefs have been protected from destructive fishing practices.

\section{Marine Areal Database for Norwegian Waters (MAREANO)}

The goal of the MAREANO project is to provide detailed habitat information in support of management plans for Norwegian waters. It was started in 2005 to fill knowledge gaps within the area outside Lofoten that was closed to oil explorations before the revision of the BSMP. This precautionary closure (Fig. 2, 3) was established to prevent oil extraction in a vulnerable and valuable marine area identified in the Barents Sea management plan until more knowledge was available.

In addition, two new management initiatives were implemented in Norway in 2009: the Marine Resources $\mathrm{Act}^{3}$ and the Nature Diversity Act ${ }^{4}$ which both affected spatial allocations to fisheries and oil exploitation. They also highlighted ecosystem management by requiring that all marine organisms caught in the fisheries be reported and that management of marine diversity applies to all levels of the ecosystem from population genetics to habitat diversity.

The MAREANO project mapped an area of 200,000 $\mathrm{km}^{2}$ from 2006 through 2017. Methods were developed for mapping habitats and biotopes including a procedure for producing maps of predicted biotopes that combined information on the distribution of biological communities with environmental factors and indicators (Buhl-Mortensen et al., 2009; Buhl-Mortensen et al., 2015). Based on the MAREANO mapping, detailed distribution of sensitive and threatened

\footnotetext{
${ }^{3}$ https://www.regjeringen.no/globalassets/up load/FKD/Vedlegg/Diverse/2010/MarineRe sourcesAct.pdf

${ }^{4}$ https://www.regjeringen.no/en/dokumenter/
} nature-diversity-act/id570549/ habitats, such as coral gardens and sponge communities, have been provided for the particularly valuable and vulnerable areas identified in the Barents Sea Management Plan (Fig. 3b).

MAREANO also has provided information on such fisheries impacts as trawl marks on the bottom substratum (Fig. 3a) and effects on benthic megafauna, like sponges and corals (Buhl-Mortensen et al., 2015). Trawl impacts were quantified by counting trawl marks along video transects; visible impact was most intense at the Tromsøflaket Bank and in certain regions in the Eggakanten area (Fig. 3a). However, no clear relationship between the satellite tracking data of trawling vessels and the abundance of trawl marks could be established, likely because varying sediment type and current conditions are major factors influencing severity and longevity of trawl marks. This was supported by the observation that in heavily fished areas, more trawl marks are visible on soft bottom than on hard bottom substrate (Buhl-Mortensen et al., 2016; Buhl-Mortensen and Buhl-Mortensen, 2017).

To quantify the effects of bottom trawling, the density of benthic megafauna taxa (e.g., sponges and corals) was studied in video transects from areas of varying fishing intensities (FI) using vessel monitoring system data. Both density and diversity of megafauna were lower in areas with high FI and even low trawling frequency had a negative effect. Vulnerability of the bottom organisms depended on their size, position in the substratum, mobility, and life span/cycle. The effects of bottom trawling on both the substrate and benthic fauna were considered and led to an increased focus on managing the ecosystem effects of fisheries on bottom habitat and benthic fauna (Meld, 2011).

As a result of the mapping by the MAREANO program, the exact position of many reefs is now available and accessible to fishermen using marked seafloor maps, since a law was passed in 1999 making it illegal to trawl on known coral reefs. The new informa- tion on locations of coral reefs and effects of bottom trawling on megafauna in the Barents Sea has aided the revision of coral protection areas and is intended to lead to a selection of MPA's that will also protect other vulnerable habitat, such as for sponges and sea pen, from the effects of fishing and oil or gas exploration. These seafloor maps will be useful in achieving the new management objective of the Lofoten-Barents Sea plan, specifically "avoiding damage to vulnerable and valuable marine habitat."

Due to the complex resource management system in Norway involving several institutions and ministries, this process has been time-consuming and cumbersome. Therefore the ultimate management goal of establishing closures and protecting the vulnerable habitat areas has not yet been achieved.

\section{Northeast Atlantic Cod Management Complex (Norwegian Waters)}

The Atlantic cod is an important fish species for the fishermen along the Norwegian coast. North of lat. $62^{\circ} \mathrm{N}$ the Atlantic cod management complex is managed under a merged quota and composed of two separate management units: the larger Northeast Arctic Cod subgroup (NEAC) and the much smaller Norwegian Coastal Cod subgroup (NCC). From the mid-1970's to 2003 the NCC annual quota of 40,000 $\mathrm{t}$ was added to the 5-10 times larger quota for NEAC. The total quota has thus been driven mainly by the state of the NEAC stock.

The NCC spawn all along the Norwegian coast at the same time as the NEAC and in some areas, like in Lofoten, overlap the NEAC spawning areas. Since neither fishermen nor buyers can identify the stock of individual fishes by morphology, stock-specific quotas alone will not adequately protect the NCC. The goal of this MPA is to protect the NCC in the Atlantic cod management complex from overfishing during the fishery targeting spawning NEAC. The rebuilding plan for NCC north of lat. $62^{\circ} \mathrm{N}$ aims to gradually 
reduce fishing mortality until research surveys show biomass levels similar to the years 1995-98, when NCC biomass was considered healthy.

The highly migratory NEAC migrate from the feeding area in the Barents Sea to the Norwegian coast to spawn. The main spawning area is the waters east and west of the Lofoten Islands, while a smaller component spawns at various locations along the coast: from Finnmark in the North to Møre in the south, with Borgundfjorden being one of the most important southern spawning grounds. In contrast, the NCC spawn all along the Norwegian coast, and overlap with the NEAC. The fishing intensity on spawning coastal cod has been particularly high in Lofoten and Borgundfjorden areas due to the increased fishing efforts during the spawning runs of the NEAC. Before the mid-1970's, NCC was managed as part of the NEAC stock. However, due to continued decline in NCC survey biomass, the International Council for the Sea (ICES) advised zero catch for the years 2004-11 (ICES, 2009, 2012) and recommended establishing a recovery plan to rebuild the NCC stocks with separate allocations between the two subgroups.

The NCC fishery is regulated much like the NEAC fishery: minimum catch size and mesh size on fishing gears, restriction on bycatch of undersized fish, closure of areas having high densities of juveniles, and seasonal and area restrictions. In recent years additional restrictions on vessel size and fishing gears have been introduced in the fjords and some coastal areas to protect the coastal cod. A rebuilding plan was put in operation in 2011, with closures of spawning grounds during the spawning season as one important regulation tool. To date, seasonal closures have been conducted in two spawning areas: Henningsværstraumen since 2005 and Borgundfjorden since 2009 (Fig. 4). These two areas are known to be important spawning grounds for NCC, but they are also frequented by NEAC during peak spawning.

The criteria for choosing closed areas were based on monitoring the

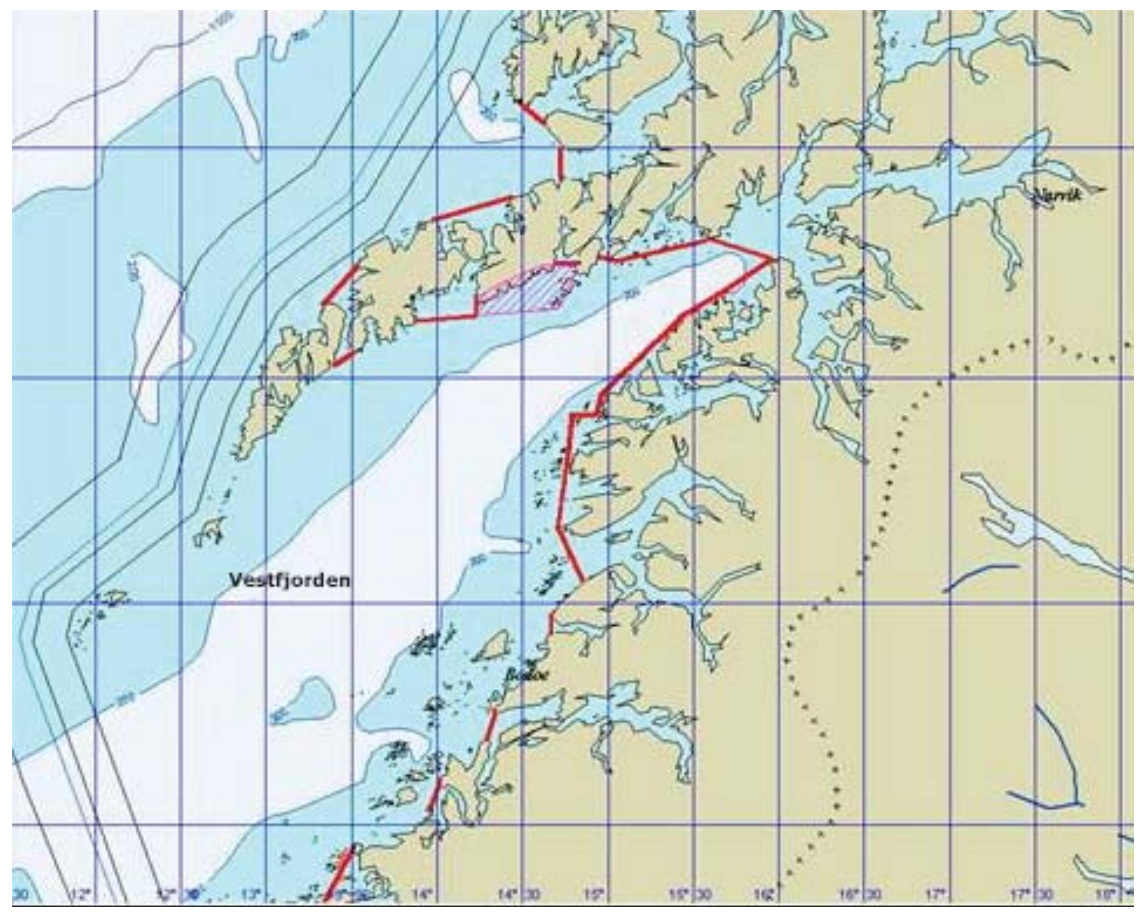

Figure 4.-The shaded area is the closed area in the Lofoten Islands. The red line is the "fjordline" which is the inner border for fishing with vessels larger than 69 feet in the period 1 January to 10 April. The rest of the year these vessels must move outside the "baseline". The area inside the fjordline is only open for vessels smaller than 50 feet, and Danish Seine is not allowed.

fraction of NCC to NEAC in the surrounding areas. The closure is put into effect by the Norwegian Directorate of Fisheries when the proportion of spawning NCC is $30 \%$ of the total spawning cod population. The area in the Lofoten Islands $\left(\approx 200 \mathrm{~km}^{2}\right)$ is closed to all fishing activity from 1 Jan. to 30 June, except for fishing with fishing rod and handlines (Fig. 4).

In 2012 the regulations were changed to allow small local vessels (smaller than $11 \mathrm{~m}$ ) to fish in the area. The area is opened for gillnet fisheries with vessels smaller than $15.2 \mathrm{~m}$ if the percentage of NCC in the commercial catches outside the closed area is < $30 \%$. This occurred in 2011, and again in 2012, when the percentage of NCC in the catches was $<10 \%$. The area in Borgundfjorden (Fig. 4) is closed to all fishing from 1 March to 30 April, except for fishing with handlines and fishing rods. The criteria for opening this area are the same as in the Lo- foten Islands, but the limit has never been reached.

\section{North Sea Lesser Sandeel}

The goal of the MPA's for lesser sandeel, Ammodytes marinus, was to mitigate the effects of local overfishing on the sandeel stocks by using area-based management tools. Rotational fishing closures are the type of MPA's used for sandeel in Norway. Lesser sandeel is a small species that buries itself in the sand during most of its life. Because of the species' dependency on suitable habitat, sandeel fishing grounds are distributed in the North Sea in a spatial patchwork (Fig. $5)$. The high abundance of sandeel in the North Sea has made it a target for a commercial fishery since the 1950's.

Sandeel are trawled during the daytime when the fish are feeding in dense schools. Sandeel have supported the largest fishery in the North Sea with average annual landings of $\sim 800,000$ 


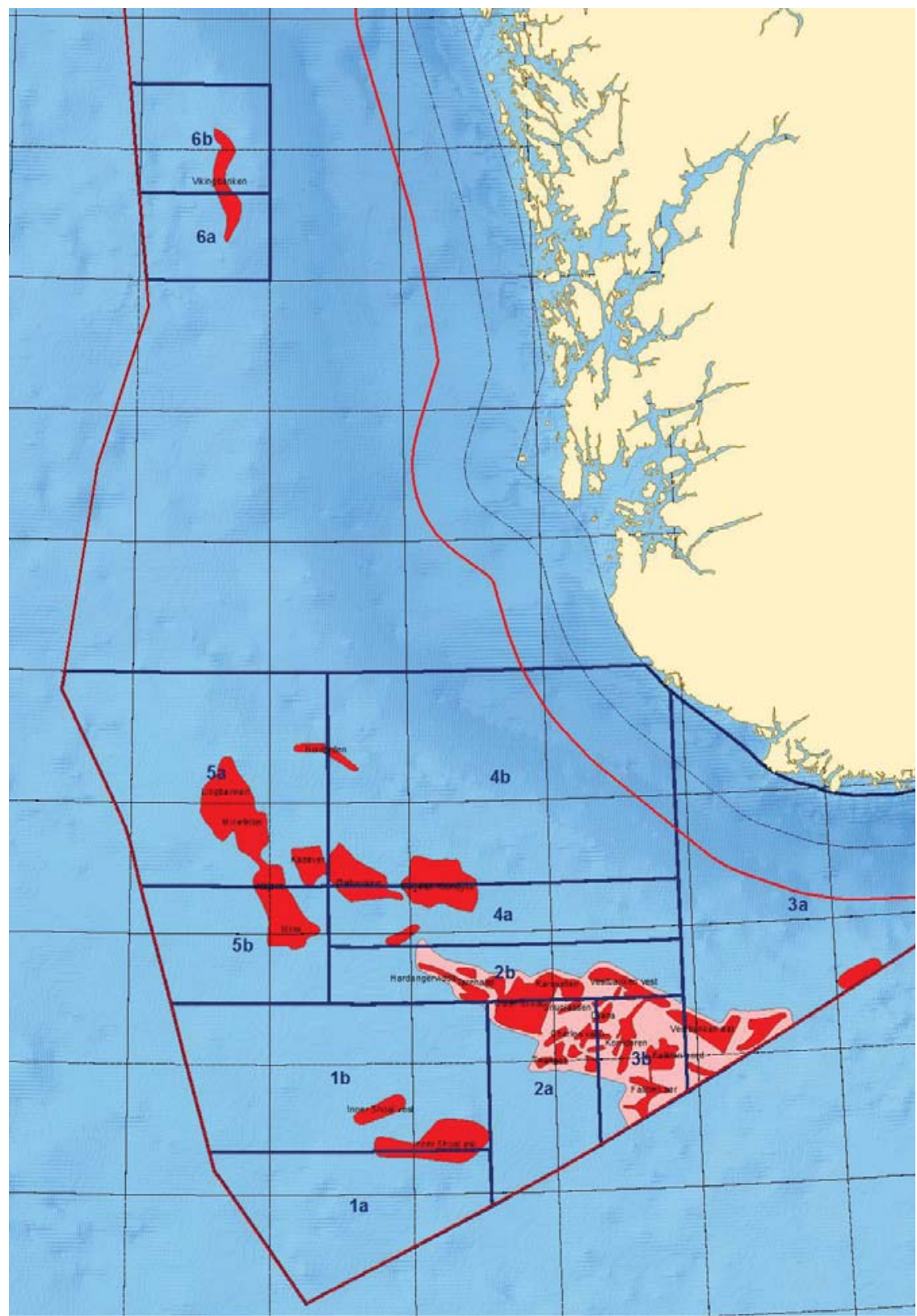

Figure 5.- Sandeel fishing grounds in the Norwegian EEZ. Red indicates trawling areas, pink scattered sandeel populations in areas that are too small for trawling (natural refuges), and blue lines depict the new spatial management plan.

$\mathrm{t}$ during the past three decades. However, in 2003 landings dropped suddenly to $\sim 300,000$ t. The decrease was particularly severe in the Norwegian EEZ (90-95\% in some years), where several fishing grounds have not provided landings during the last decade (ICES, 2009). ed by substantial spatial contraction of the stock along with the substantial decline of available biomass. Individual sandeel fishing grounds are split into two subareas. One subarea is fished in one year and the second the following year. If the abundance on a fishing ground falls below a predefined level, the entire fishing ground is closed.

The total allowable catch (TAC) for all open areas was estimated using biomass estimates from acoustic surveys. Sandeel become mature at the age of two. Hence, alternating closures of two subareas of each fishing ground is intended to maintain local spawning stocks, prevent local depletions, ensure sufficient prey for predators, and maximize fishing yield. This spatial management regime was introduced in 2010. To date, the results have been promising. All fishing grounds that were initially opened in 2010 were still open for fishing in 2012, even though recruitment was poor in 2010 and 2011 (ICES, 2012), a situation that would normally have resulted in overfishing and local depletions. Since the area closures have been put into effect, the estimated biomasses have been above the threshold level that would have closed fishing in three of the fishing grounds.

Although the results of the new spatial management regime have been promising, there are still questions that remain unanswered before concluding that these MPA's are effective in the long term. First, sandeel prefer relatively coarse sand, and when fish are removed from their optimal habitat by fishing, the fished area is likely to be replenished by sandeels from more marginal habitats (Holland et al., 2005; Wright, 1996). Thus, if the preferred sandeel habitat lies in the area open to fishing and the quality of the habitat is substantially lower in the closed area, then migration from the closed subarea into the area open to fishing could occur within one fishing season, and the local stock could still be vulnerable to overfishing.

If, on the other hand, migration into the closed area from the open area 


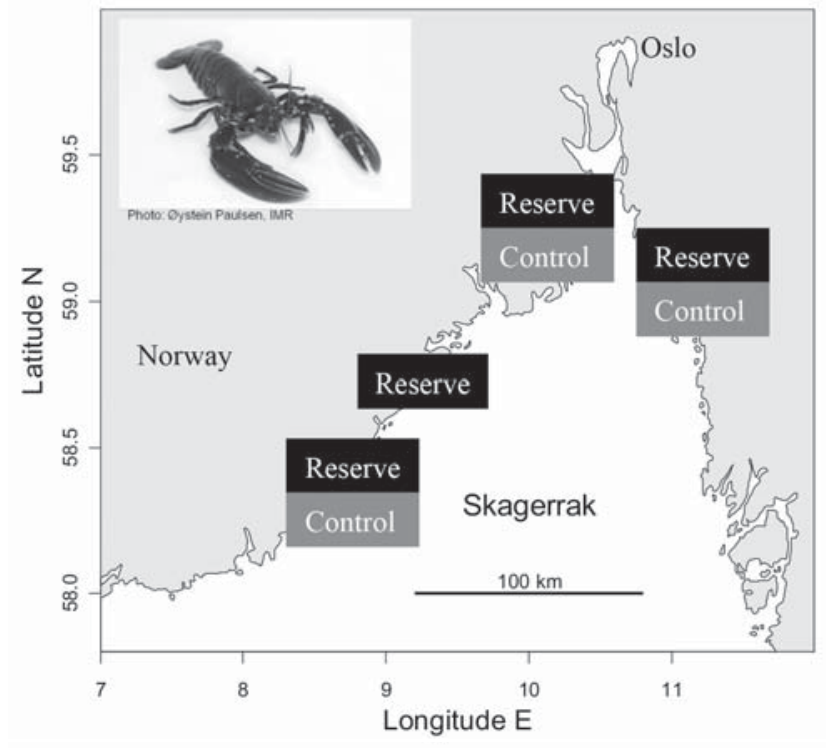

Figure 6.- - Lobster reserves and control areas (for evaluating reserve effects on population density and demography) on the Norwegian Skagerrak coast. For detailed maps, see Pettersen et al. (2009).

should occur between two fishing seasons, then this could reduce fishing yield. These problems can be addressed by redesigning the subareas, based on the acoustic survey. Second, the underlying mechanism of recruitment remains unresolved, although empirical evidence suggests that local spawning stocks are important for local recruitment. Therefore it is possible that there are other causes for local recruitment failures, such as changes in local retention for sandeel larvae or changes in the local availability of planktonic prey.

MPA's for Lobster

and Cod in Coastal

Skagerrak, Southern Norway

A network of MPA's has been implemented specifically targeting the European lobster, Homarus gammarus, along the coast of southern Norway. The main objective is to provide a scientifically based evaluation of MPA's as a management tool for restoring this intensively harvested population (Kleiven et al., 2011; Moland et al., 2011). The European lobster is a prized catch for both recreational and commercial fishermen in the Skager- rak, the northeastern area of the North Sea. However, since the 1950's the lobster population in this region has been in severe decline (Pettersen et al., 2009). In response to this population decline, four lobster MPA's were established in September 2006 (Fig. 6). The MPA's are small $\left(0.5-1 \mathrm{~km}^{2}\right)$ and were intended to be experimental in nature, excluding the use of standing gear such as traps, longlines, and gillnets. Hook and line fishing for species such as the Atlantic cod is still permitted inside the MPA's.

The lobster MPA's were designed in collaboration with local commercial fishermen. Recreational fishermen, on the other hand, were not included in the implementation process although many of them expressed that desire (Pettersen et al., 2009). Recreational fishermen are an important stakeholder group and contribute the majority of fishing effort for lobster in Skagerrak (Kleiven et al., 2011). Therefore, one lesson learned was that recreational fishermen should be included in future MPA implementation and assessment processes.

The lobster MPA's have been monitored annually since 2004 (3 years before implementation). Since 2006 (before implementation), adjacent control areas, where lobster fishing was permitted, were added to the study. The survey design therefore follows the BACIP (Before-AfterControl-Impact-Pairs) design as advocated in other studies (Russ, 2002) as a general guide to measuring reserve effects. By 2010 (4 years after MPA designation), lobster population density had almost tripled inside the MPA's and there was also a significant increase in mean body size (Moland et al., 2013). A similar increase in population density and body size was not observed in the control areas. These results indicated that MPA's can be a useful management tool in rebuilding lobster populations in northern temperate waters. Note, however, that spillover and recruitment benefits to adjacent fished areas have not yet been observed.

In one reserve and control area, the local population of Atlantic cod has also been monitored. By 2010 both the survival and population density of larger cod had increased inside the MPA compared to adjacent control areas (Moland et al., 2013; Fernández-Chacón et al., 2015). Coastal cod in this region is known to be highly stationary, with fjord-specific local populations that are also depleted and intensively harvested by commercial and recreational fishermen (Knutsen et al., 2003; Olsen and Moland, 2011; Kleiven et al., 2016). Therefore, it is perhaps not surprising that Atlantic cod also benefit from the MPA's due to the exclusion of fixed fishing gear. Informed by these encouraging results, another MPA was implemented in 2012 to protect a local Skagerrak fjord population of Atlantic cod. This MPA covers about $1.5 \mathrm{~km}^{2}$ of the fjord around a key cod spawning area and excludes all forms of fishing and thus is Norway's only true no-take marine reserve. It offers protection to the coastal cod population, although longterm effects on recruitment and population density of larger fish still needs to be evaluated (Villegas-Ríos et al., 2017). 


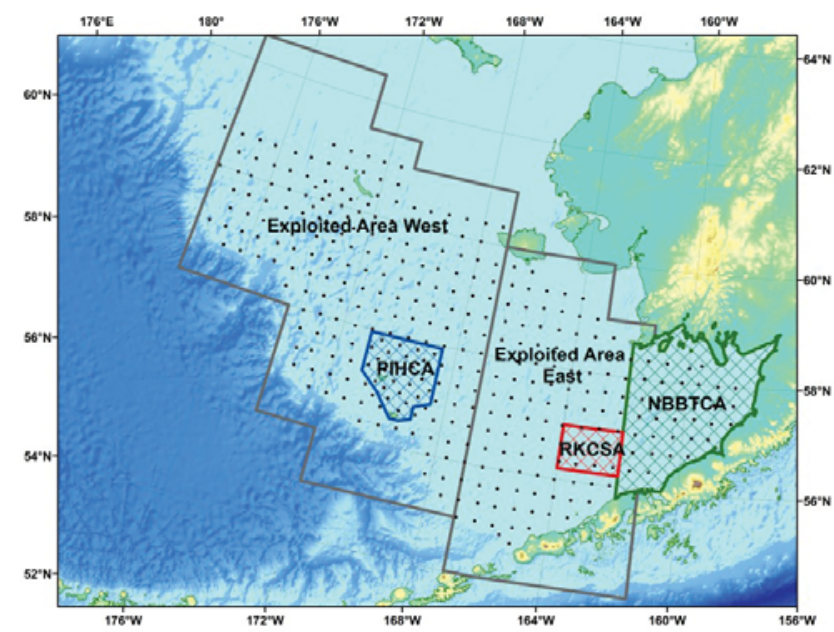

Figure 7.- Three principal large-scale marine protected areas in the eastern Bering Sea: the Pribilof Islands Habitat Conservation Area (PIHCA, in blue), the Red King Crab Savings Area (RKCSA, in red), and the Nearshore Bristol Bay Trawl Closure Area (NBBTCA, in green). Also shown are the nominal locations of bottom trawl sampling stations (dots) in the annual eastern Bering Sea bottom trawl survey conducted by the Alaska Fisheries Science Center and the two "exploited" areas used to classify individual survey hauls ("Exploited Area West," "Exploited Area East"; grey outlines).

\section{Northeast Pacific (U.S. Waters)}

Area closures have been used as fishery management tools off Alaska long before they became known as Marine Protected Areas. Currently, there are several regulatorily established Habitat Conservation Areas, such as seamounts, coral protection areas, and no-trawl zones. In one example, we focus on the first such "MPA" in Alaska waters; it was established in 1939 when Cook Inlet and all waters east of long. $150^{\circ} \mathrm{W}$ were closed to trawling for red king crab, Paralithodes camtschaticus, in an effort to reduce exploitation of red king crab and Pacific halibut, Hipploglossus stenolepis (Witherell and Woodby, 2005). At present, more than 40 MPA's have been established by fishery managers in federal waters off Alaska (i.e., beyond the $3 \mathrm{nmi}$ state waters boundary) to address a diverse range of purposes including protecting ecological structure and function, improving scientific understanding, conserving habitat, protecting vulnerable stocks, and preserving cultural resources (Witherell and Woodby, 2005).

\section{Red King Crab and Blue King Crab Savings Area}

Three large-scale MPA's in the eastern Bering Sea are evaluated here (Fig. 7). The three large closed areas are not "marine reserves" (sensu Lubchenko et al., 2003) where no extractive activities are allowed. Rather, the primary goal of all three closures is sustainable production and exploitation of local crab stocks (red king crab in the Nearshore Bristol Bay Trawl Closure Area (NBBTCA), and the Red King Crab Savings Area (RKCSA), and blue king crab in the Pribilof Islands Habitat Conservation Area (PIHCA)) by prohibiting bottom trawling and therefore eliminating crab bycatch and benthic habitat disturbance from groundfish trawl fisheries. Targeted fishing for crab using pot gear is allowed, as is fishing for groundfish using longline, pot, and, in some instances, pelagic trawl gear.

The NBBTCA $\left(65,000 \mathrm{~km}^{2}\right)$ was established in 1997 as a year-round closure to all trawling (bottom and pelagic) in all of Bristol Bay east of long. $162^{\circ} \mathrm{W}$, except for a small area that is seasonally open to trawling in the spring (from 1 Apr. to 15 June). This expanded previous smaller protected areas in Bristol Bay in place from 1975 until 1983, to protect the Bristol Bay red king crab stock from effects of groundfish trawl fisheries and to reduce gear interactions between the crab pot and groundfish trawl gears.

In 1983 the area was opened to developing domestic trawl fisheries, even though the crab stock had collapsed in 1981. In 1986, a $27,000 \mathrm{~km}^{2}$ area in the middle of Bristol Bay was closed to bottom trawling and in 1997 this was expanded to become the NBBTCA. The adjacent RKCSA $(14,000$ $\mathrm{km}^{2}$ ) was also permanently closed to bottom trawling north of lat. $56^{\circ} 10^{\prime} \mathrm{N}$. South of lat. $56^{\circ} 10^{\prime} \mathrm{N}$ to $55^{\circ} \mathrm{N}$, the RKCSA is open to limited bottom trawling, but only in years when a directed fishery for Bristol Bay red king crab is also allowed. Northern rock sole are the primary target of bottom trawling in the limited area. Finally, the PIHCA $\left(24,000 \mathrm{~km}^{2}\right)$ prohibited all trawling and dredging beginning in 1995 to protect the local stock of blue king crab.

Data from the long-term fishery-independent trawl survey in the eastern Bering Sea (Lauth, 2011) conducted by the Alaska Fisheries Science Center (AFSC) was used to perform a BeforeAfter-Control-Impact (BACI) analysis (Stewart-Oaten et al., 1986) of the effects of the three large MPA's on the abundance of several ecologically and commercially important groundfish and crab stocks. Each survey station was classified into one of five analysis regions (Fig. 7): two areas (control sites) that have been continuously open to exploitation ("Exploited Area West," "Exploited Area East") and the three closed areas (impact sites).

We calculated mean CPUE for each analysis area by survey year as an index of relative abundance by species within each area (Fig. 8). Mean CPUE from the AFSC summer bottom trawl survey is routinely used to track changes in fish and crab abundance in the stock assessments for most federally managed stocks. The period 1990-94 was 

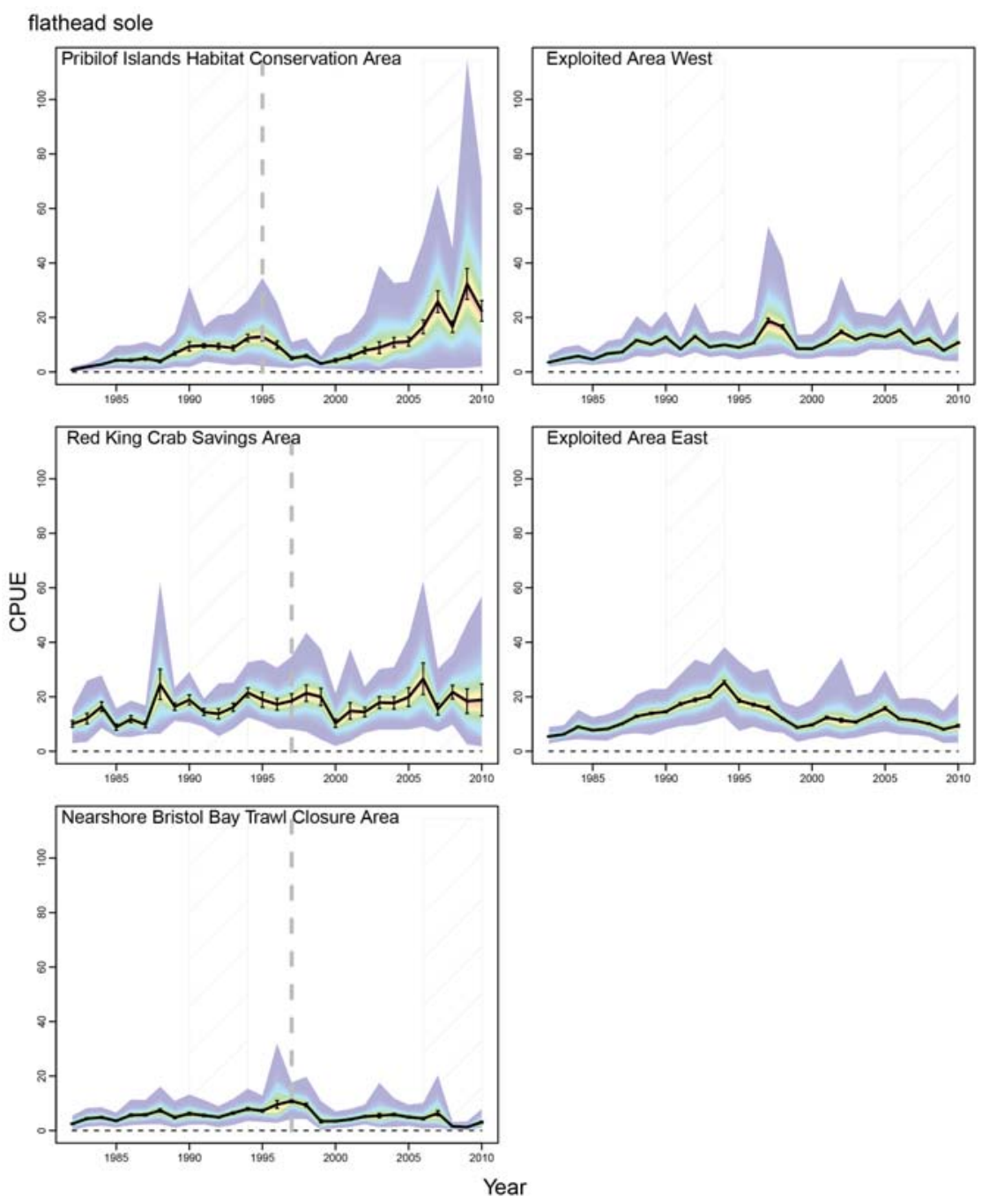

Figure 8.-Example time series for flathead sole from each analysis area of mean catch per unit of effort (black line), based on 10,000 bootstrap samples, with bootstrapped standard error (error bars) and confidence intervals (colored intervals). The dashed grey vertical line indicates the year in which each closed area was established. The grey hatched areas indicate the "before" (1990-94) and "after" time periods used in the before-after-control-impact (BACI) analysis.

defined as the "before" time period and 2006-10 as the "after" time period in the BACI analysis. We then tested whether the average ratio of abundance inside to outside each closed area changed in a positive manner from before to after the MPA was implemented. We included 5 flatfish species, 4 other groundfish species, 2 crab species, and 5 habitatforming invertebrate species/taxa in the analysis (Table 1).

We were able to make 35 valid comparisons (out of a possible 48) (Table
( $\mathrm{p} \leq 0.05$, not accounting for multiple comparisons) associated with at least one of the closed areas for all five flatfish species, three of the four "other" groundfish species, two of the five habitat-forming benthic invertebrate taxa, but neither of the crab species (Table 1). Only rock sole, flathead sole, and Pacific cod exhibited positive effects in more than one closed area.

Conversely, we found significant negative changes in relative CPUE ( $p$ $\leq 0.05$ ) associated with at least one of the closed areas for two of the five flatfish species, two of the four "other" groundfish species, one of the two crab species, and two of the five habitat-forming invertebrate taxa. However, only Tanner crab and sea peaches exhibited significant negative effects in more than one closed area. The largest significant negative effects ( $\mathrm{p} \leq$ 0.05 ) occurred for sea peaches in the RKCSA and sea onions, Boltenia sp., and Tanner crab in the NBBTCA.

The three MPA's we examined were closed to bottom trawling to reduce bycatch of several crab species in fisheries for groundfish. These closed areas were open to other gear types and were not intended to restrict the crab fisheries. Based on fishery observer data, compliance with these closed areas by the groundfish bottom trawl fishery appears to be good, and substantial effort by the groundfish trawl fisheries in these areas prior to closure has been eliminated or displaced (Fig. 9). We found no significant increases in relative abundance in any of the three closed areas for the two crab species (snow and Tanner) we examined.

Quite the opposite, we found that relative abundance decreased significantly for Tanner crab in both the NBBTCA and RKCSA areas. However, this may reflect relatively higher fishing mortality on crab stocks within the areas closed to bottom trawling because targeted crab fisheries are conducted within these areas. Of the 14 other taxa (9 groundfish species and 5 habitat-forming benthic invertebrate taxa) which we were able to examine, only rock sole exhibited significant 


\begin{tabular}{|c|c|c|c|c|c|c|c|}
\hline \multirow[b]{3}{*}{ Common Name } & \multirow[b]{3}{*}{ Taxonomic name } & \multirow{2}{*}{\multicolumn{2}{|c|}{$\begin{array}{l}\text { Nearshore Bristol Bay } \\
\text { Trawl Closure Area } \\
\text { Exploited Area East }\end{array}$}} & \multirow{2}{*}{\multicolumn{2}{|c|}{$\begin{array}{c}\text { Red King Crab Savings Area } \\
\text { Exploited Area East }\end{array}$}} & \multirow{2}{*}{\multicolumn{2}{|c|}{$\begin{array}{l}\text { Pribilof Islands HCA } \\
\text { Exploited Area West }\end{array}$}} \\
\hline & & & & & & & \\
\hline & & Effect size & Significance & Effect size & Significance & Effect size & Significance \\
\hline \multicolumn{8}{|l|}{ Flatfish } \\
\hline Alaska plaice & Pleuronectes quadrituberculatus & 0.5725 & 0.0068 & 0.1787 & 0.2347 & -0.5613 & 0.9954 \\
\hline Arrowtooth flounder & Atheresthes stomias & - & - & 0.7330 & 0.0089 & 0.1130 & 0.3143 \\
\hline Flathead sole & Hippoglossoides elasodon & 0.0233 & 0.4799 & 0.8199 & $<0.0001$ & 0.7706 & 0.0037 \\
\hline Rock sole & Lepidopsetta spp. & 0.2857 & 0.0203 & 0.4389 & 0.0197 & 0.9775 & 0.0001 \\
\hline Yellowfin sole & Limando aspera & 0.4183 & 0.0021 & -0.1703 & 0.8437 & -0.5510 & 0.9866 \\
\hline \multicolumn{8}{|l|}{ Other groundfish } \\
\hline Great sculpin & Myaxocephalus polyacanthocephalus & 0.3759 & 0.0987 & -0.4956 & 0.9157 & 0.9757 & 0.0020 \\
\hline Pacific cod & Gadus macrocephalus & -0.6345 & 0.9946 & 0.7888 & 0.0035 & 0.4795 & 0.0207 \\
\hline Plain sculpin & Myaxocephalus jaok & 0.3891 & 0.0282 & - & - & - & - \\
\hline Walleye pollock & Theragra chalcogramma & -0.7382 & 0.9876 & 0.0999 & 0.4076 & 0.2579 & 0.0952 \\
\hline \multicolumn{8}{|l|}{ Crab } \\
\hline Snow crab & Chionoecetes opillo & - & - & - & - & 0.0575 & 0.5871 \\
\hline Tanner crab & Chionoecetes bairdi & -1.4389 & 1.0000 & -0.6776 & 0.9957 & - & - \\
\hline \multicolumn{8}{|c|}{ Habitat-forming invertebrates } \\
\hline Mussels & Mytiladae & -0.4013 & 0.7006 & - & - & - & - \\
\hline Sea onions & Boltenia & -1.5017 & 1.0000 & - & - & - & - \\
\hline Sea peaches & Halocynthia & 7.3070 & 0.0029 & -2.4275 & 0.9988 & -0.8570 & 0.9505 \\
\hline Sea potato & Styela rustico & - & - & - & - & 0.6171 & 0.1531 \\
\hline Sea raspberries & Eunephthya & 1.6204 & 0.0001 & - & - & -0.5675 & 0.7170 \\
\hline
\end{tabular}
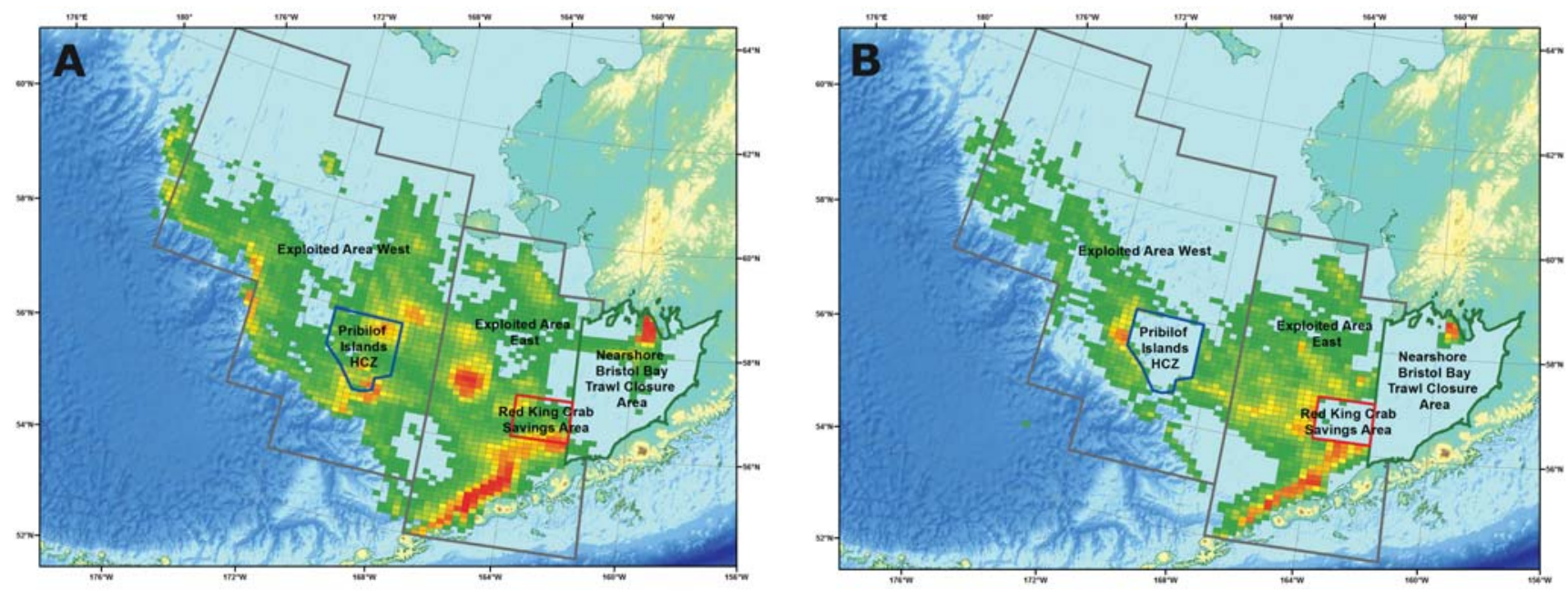

Figure 9.-Distribution of bottom trawls in the eastern Bering Sea groundfish fisheries, as recorded by fishery observers, for 1990-94 (prior to area closures; left) and 2006-10 (after area closures; right), binned in $0.5^{\circ}$ longitude $x 0.2^{\circ}$ latitude cells. Cells with fewer than 3 hauls/time period are not shown due to confidentiality restrictions. The same color scale is used in both maps; colors run from green (few hauls) to red (many hauls).

positive increases in relative abundance across all three closed areas.

As a group, the flatfish species appear to have benefited most consistently from the closures, with significant positive effects on relative abundance in over half (8 of 14) of the cases examined. This may be because flatfish are relatively stationary species com- pared to other species targeted by the bottom trawl fishery, such as Pacific cod. Pacific cod is also harvested in the eastern Bering Sea in large quantities, but it moves across the boundaries of the closures and therefore observation of a biomass increase inside the closed area is less likely for this species.
Altogether, we found 14 instances out of 35 taxon/closed-area combinations tested that exhibited "significant" increases in the relative abundance of the taxon in the closed area in the time following the closure. Conversely, we found 9 instances in which the relative abundance of the taxon in the closed area declined significantly. To 
some extent, these results suggest that the response to areas closed to bottom trawling is inconsistent across species and areas for many species. The closed areas have certainly had relatively little positive effect on the targeted crab stocks. Closing these areas to bottom trawling alone, but not to crab harvest by pots, does not appear to be enough to recover depleted crab stocks.

\section{Aleutian Islands}

\section{Coral Protection Area}

The Aleutian Islands coral protection areas (Fig. 10) were established to protect vulnerable habitat from the impacts of bottom trawling. Future bottom trawling was limited to where there had been medium or high historical bottom trawl effort between 1990 and 2001. All areas which had low or zero effort at fishable depth (over $58,000 \mathrm{~km}^{2}$ ) were closed to all future bottom trawling in 2007 as a precautionary measure (NMFS, 2001). In addition, bottom trawling in areas that had a high rate of bycatch of corals and sponges and low catch rates was prohibited.

This closure created an MPA in the Aleutian Islands that closed over 75\% of fishable depths (up to $1,000 \mathrm{~m}$ ) to all bottom trawling, leaving an area of $26,555 \mathrm{~km}^{2}$ open to trawling in the Aleutian Islands, containing 94\% of past effort and 97\% of catch. This closure was only possible because of the existing data from a large fishery observer program and close cooperation of the industry. Additional bycatch limits for coral and sponges were imposed as an additional protection measure; these were set near the upper end of the observed bycatch levels for these taxa.

There was one adjustment to the boundaries of this large MPA since its implementation in 2007, which consisted of an exchange of areas in the far western Aleutian Islands. Additionally, conservation measures to protect Steller sea lion prey implemented in 2011 (see below) closed much of the western and central Aleutian Islands to harvest of Atka mackerel and Pacific cod, the top two fisheries in the Aleu-

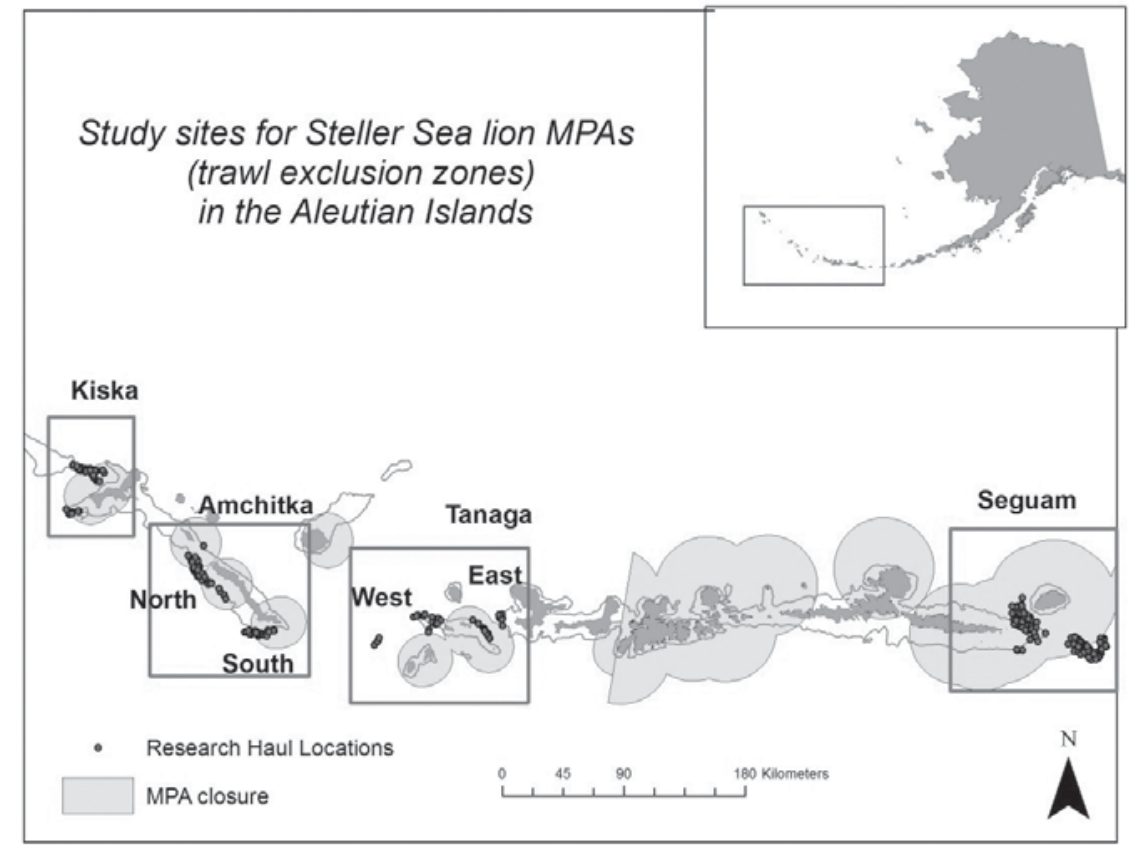

Figure 10.- Study sites and haul locations inside and outside Steller sea lion MPA's

tian Islands, which will complicate the analysis of the efficacy of the coral closures.

\section{Steller Sea Lion \\ Trawl Exclusion Zones}

The other MPA's established in the Aleutians Islands are fishing closures around Steller sea lion (SSL) rookeries (Fig. 10). The goal of these MPA's is to protect major SSL prey species from the effects of fishing within sea lion critical habitat.

The Alaska SSL population has declined by more than $80 \%$ since the 1970's (Loughlin, 1998). In 1997, the western population (west of long. $144^{\circ} \mathrm{W}$ ) was listed as endangered under the Endangered Species Act (ESA). In November 2000, a suite of protection measures was implemented to mitigate potential competition between fisheries and sea lions. Since then, 10 and $20 \mathrm{nmi}$ diameter MPA's (known as Trawl Exclusion Zones (TEZ's)) have been in place around major SSL rookeries and haulouts to protect SSL critical habitat (Fig.10)

In response to these MPA closures, NMFS conducted local-scale studies in 2002-04 and 2006-07 to examine the abundance and movement of Atka mackerel within and adjacent to the MPA's. Atka mackerel are a major prey species of the western stock of SSL (Sinclair and Zeppelin, 2002).

The potential effect of MPA closures examined for the purpose of this paper are that MPA's result in the increase of fish biomass inside the closed area. This study was originally designed as a tag release and recovery program for Atka mackerel (McDermott et al., 2005). During the tag recovery on chartered survey vessels, the area swept, catch, and species composition were recorded. We compared CPUE inside vs. outside the closed areas to examine the hypothesis of increased relative abundance of Atka mackerel inside the MPA's.

To test for differences in average CPUE inside vs. outside the MPA, we analyzed each area separately and used an ANOVA (Titco Spotfire SPLUS) with year as a factor. In the Tanaga and Amchitka areas, we further divided the study areas into subareas, Amchitka North and South and Tanaga East and West (Fig. 10). Each subarea 


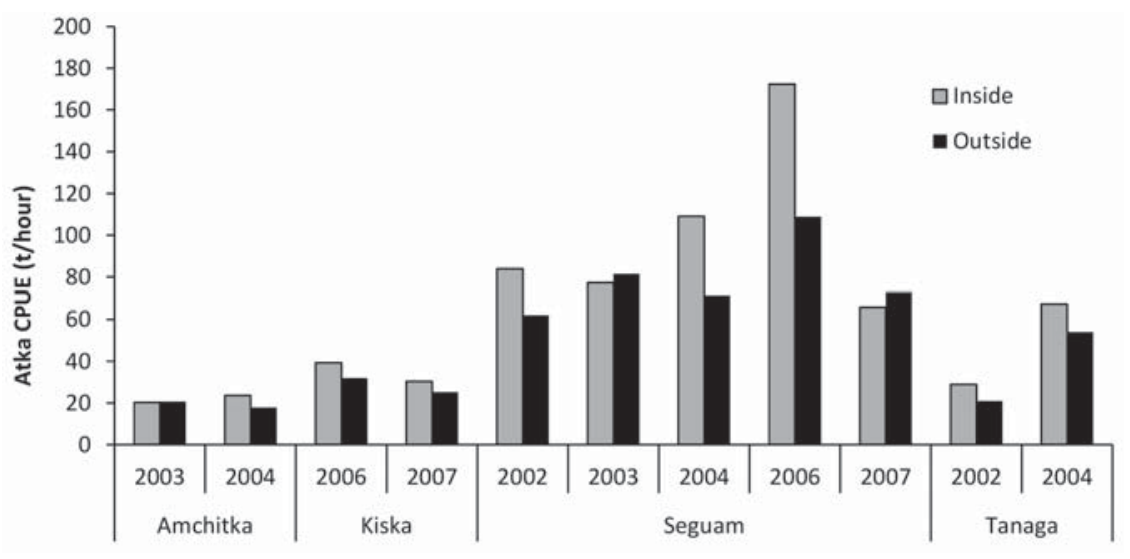

Figure 11.-Atka mackerel catch per unit of effort inside (gray) and outside (black) the trawl exclusion zones in the different study areas and years

represented a separate population center within the study area. For Tanaga and Amchitka the ANOVA included year and subarea as factors when testing for differences of CPUE inside and outside the MPA. To test for differences in mean length within study areas, we used an ANOVA (Titco Spotfire SPLUS) with year, season, and sex as factors.

Atka mackerel CPUE was significantly different inside vs. outside the MPA at Seguam Pass $(P=0.003)$ but was not significantly different at Amchitka $(P=0.84)$, Tanaga $(P=0.74)$, or Kiska $(P=0.36)$ (Fig. 11). The results of Atka mackerel CPUE differences might be explained by oceanographic and habitat differences of study areas and by the MPA size (i.e., 10 vs. 20 nmi). At Seguam Pass, for example, the MPA boundary is $20 \mathrm{nmi}$ and happens to contain a well-documented frontal region characterized by upwelling and stratified water (Coyle, 2005; Mordy et al., 2005) This area may favor feeding (Rand and Lowe, 2011) and reproduction (Cooper and McDermott, 2011). The population of Atka mackerel inside the MPA is separated from the outside population by an area of low Atka mackerel abundance which forms a natural boundary. At the Tanaga, Amchitka, and Kiska study areas, the MPA boundary is $10 \mathrm{nmi}$ and in some cases, such as Amchitka, the MPA boundary bisects
Northwest Atlantic (U.S. Waters)

\author{
Groundfish and Sea \\ Scallop Stocks in the \\ Georges Bank Ecosystem
}

MPA's (Fig. 12) were established in December 1994 to help rebuild important and severely depleted groundfish and sea scallop, Placopecten magellanicus, stocks in the Georges Bank ecosystem. In general, the MPA's were closed to bottom trawling and dredging for groundfish and sea scallops, with some limited fishing in portions of the MPA's for sea scallops, yellowtail flounder, Limanda ferruginea, and haddock, Melongrammus aeglefinus, during some periods since 1999 .

Prior to 1994, these three areas were closed during late winter and spring to protect groundfish spawning aggregations. Thus, the MPA's were not originally designed as year-round closures. Besides the closures, a number of other management measures were enacted starting in 1994. Specifically, the sea scallop and groundfish fisheries changed from open access to limited access management in 1994, with a fixed number of permits. Each permit holder was given annual days-at-sea and/or quota allocations. Gear regulations were also gradually imposed

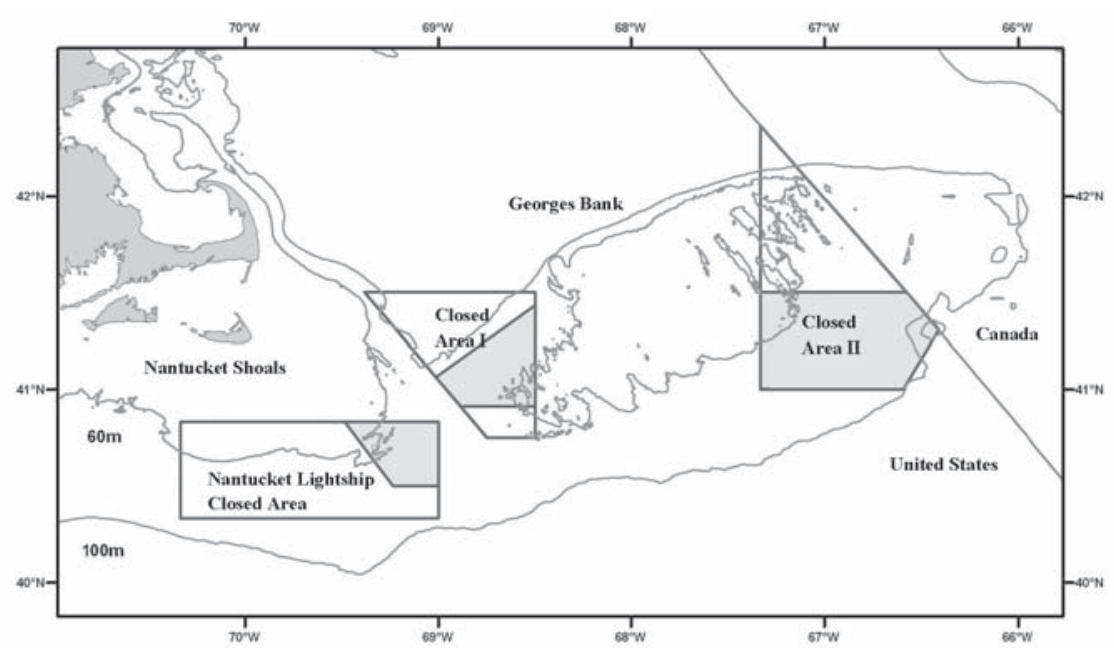

Figure 12.-Chart of Georges Bank and Nantucket shoals, showing the three closed areas. The shaded portions are sea scallop access areas, where limited amounts of scallop fishing have been permitted since 1999. 
that increased dredge ring size for the scallop fishery and mesh sizes in the groundfish fishery potentially contributing to some of the stock rebuilding since 1994.

The responses to these closures of five important commercial species on Georges Bank and Nantucket Shoals are examined here: sea scallops; yellowtail flounder; goosefish, Lophius americanus (also known as monkfish or American anglerfish); haddock; and Atlantic cod. Sea scallops and goosefish are managed as separate fisheries, whereas yellowtail flounder, haddock, and cod are managed as part of the Northeast U.S. multispecies groundfish complex. The goosefish fishery was not managed prior to 1999 , but since then this fishery has been managed with days-at-sea, quotas, and gear regulations similar to the sea scallop and multispecies groundfish plans (Haring and Maguire, 2008).

Two separate stocks of yellowtail flounder are examined: Georges Bank yellowtail flounder, whose stock area includes most of Closed Areas I and II and the portions of Georges Bank outside these areas, and southern New England yellowtail flounder, whose stock area includes the Nantucket Lightship Closed Area and all other areas south and west of Georges Bank (Fig. 12). The response variables used in the analyses were estimates of overall biomass, recruitment, and fishing mortality from stock assessments. In addition, biomass trajectories in the closed and open areas were examined (Hart and Rago, 2006).

Estimated biomasses from stock assessments (Fig. 13) suggest strong responses to the closures in two stocks: Georges Bank sea scallops and Georges Bank haddock. In both cases, biomass began increasing almost immediately after the closures in 1994, and the terminal year biomass was over an order of magnitude higher than in 1994. Sea scallops inside the closed areas showed a strong response to the closures, especially in the first 6 years after closure (Fig. 14). Scallop abundance outside the closed areas has also increased, though the increase was more gradual and less than that observed in the closed areas, likely due to the effort reductions and gear restrictions.

Georges Bank yellowtail flounder appears to have had a more modest response to the closures (Fig. 13). A sharp reduction of this stock's biomass occurred between 2004 and 2005, when a "Special Access Program (SAP)" allowed substantial landings of yellowtail flounder in the southern portion of Closed Area II. The stock then began to recover due to a strong year class but appears to have declined since 2008. The biomass inside the MPA's increased substantially within the closures from 1996 to 2003, but then dropped precipitously coinciding with the SAP fishery in Closed Area II in 2004 (Fig. 14). After a recovery, mainly due to a large year class, biomass within the closures declined considerably between 2009 and 2011, even though there was no directed fishery for yellowtail flounder in the closed areas. Biomass in the open portions of Georges Bank has been low.

Biomass of southern New England yellowtail flounder remained at low levels since 1994 (Fig. 13), and has shown marginal increases within the Nantucket Lightship Closed Area (Fig. 14). Estimates of biomass in the open areas of southern New England are unavailable because the scallop survey does not cover the entire area sufficiently.

Goosefish showed little response to the closures after 1994. The modest increases that occurred after 1999 were likely due to strong recruitment and implementation of the fishery management plan in 1999 rather than to the closures. Goosefish biomass tended to be slightly less inside the closures than outside prior to the closures in 1994 , but this relationship appeared to be reversed after the closure, suggesting that the closures had a small protection effect. Biomass of the remaining two stocks, southern New England yellowtail flounder and Georges Bank cod, showed no response to the closures.

Recruitment of Georges Bank haddock and yellowtail flounder was high- er after the closures than in the period immediately prior to the closures, but even in these cases, recruitment after the closures was not higher than it was early in the time series (prior to 1964 for Georges Bank haddock and 1982 for Georges Bank yellowtail). Recruitment in Georges Bank cod and southern New England yellowtail flounder has been very poor since the closures, and the closures do not appear to have substantially affected recruitment of goosefish. Recruitment of Georges Bank sea scallops was slightly higher after the closures than before (Hart et al., 2013).

The characteristics of the six stocks examined are summarized in Table 2 . Five of the stocks were severely depleted at the time of the closures due to very high fishing mortalities. The one exception was goosefish, which did not have a directed fishery until the mid-1980's, and whose fishing mortality appears to have been fairly low prior to the closures (NEFSC, 2010). Sea scallops can swim short distances, but their movement is negligible on the scale of the closures. Yellowtail flounder, goosefish, and haddock are all capable of greater movement than scallops, but none typically undergo large-scale migrations, and so their mobility is classified as moderate. Cod can move several hundred kilometers during seasonal migrations; therefore they are classified as highly mobile. Haddock, cod, and both yellowtail stocks all showed evidence that recruitment had decreased as the stock biomass declined, suggesting recruitment overfishing, whereas there was little or no evidence for recruitment overfishing of scallops and goosefish.

\section{Discussion}

\section{Achieving MPA Goals}

The MPA's discussed in this paper can be divided into two broad groups based on the stated goals: 1) to conserve habitat or fish species to preserve the functioning of a healthy ecosystem (Habitat Conservation MPA's), and 2) to prevent overfishing or stock depletion (Fishery Management MPA's). 

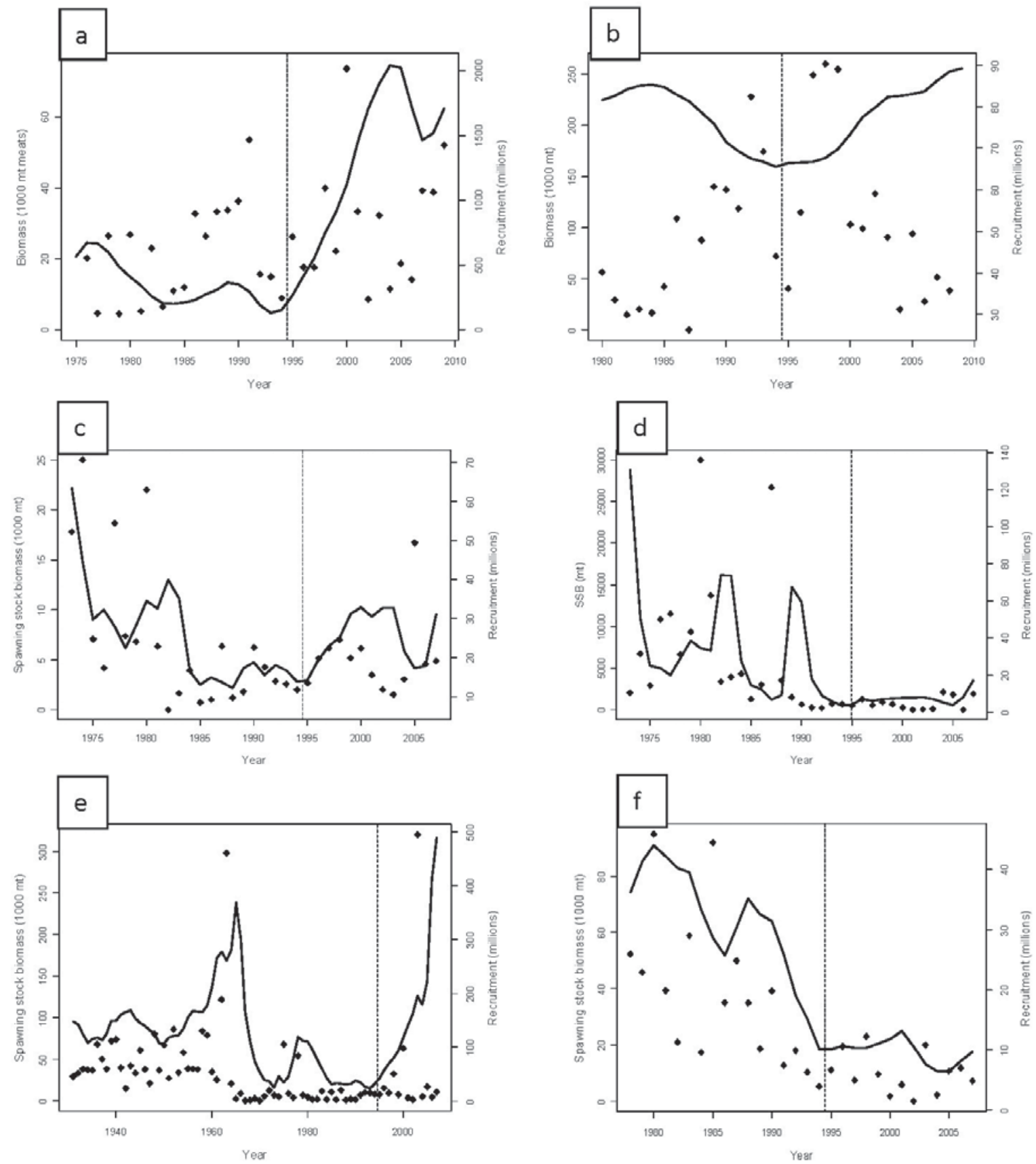

Figure 13.-Estimated biomass (lines) and recruitment (points) for (a) Georges Bank sea scallops, (b) goosefish, (c) Georges Bank yellowtail flounder, (d) southern New England yellowtail flounder, (e) Georges Bank haddock and (note that recruitment is on a log scale) (f) Georges Bank cod, from the latest stock assessment for each stock (NEFSC, 2010, Legault et al., 2011, Brooks et al., table 2, footnote 1; O'Brien et al., text table 2, footnote 2)). The dashed vertical line indicates the time of the closures. 

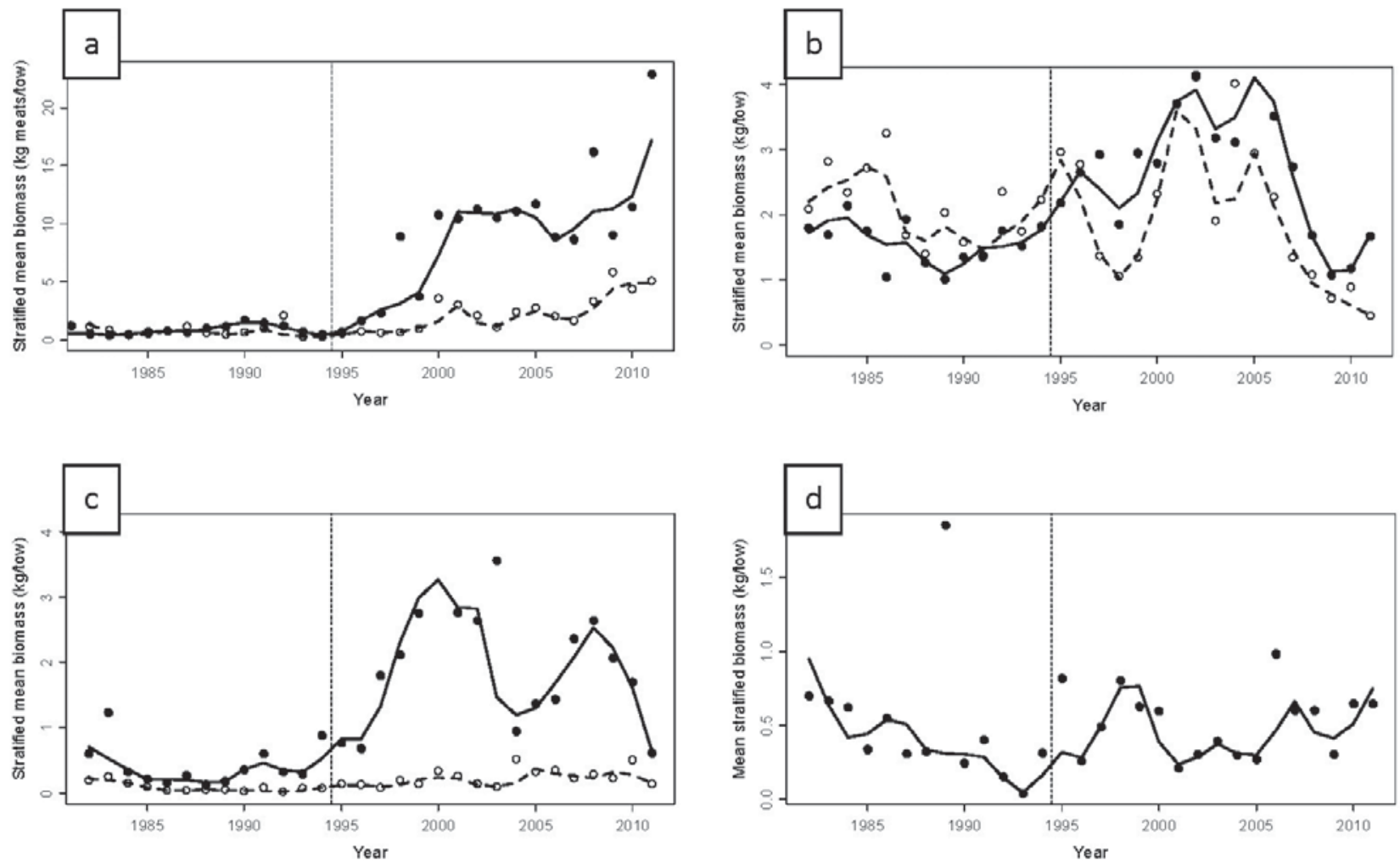

Figure 14.-Biomass indices for closed (solid points) and open portions (open circles) of Georges Bank and surrounding areas for (a) sea scallops, (b) goosefish, (c) Georges Bank yellowtail flounder, (d) southern New England yellowtail flounder. The solid and dashed curves are lowess smoothed versions of the closed and open data, respectively $(\operatorname{span}=0.2)$. The dashed vertical line indicates the time of the closures.

\section{Habitat Conservation MPA's}

The habitat conservation MPA's discussed in this paper (vulnerable habitat in the Barents Sea, sandeel spawning areas in the North Sea, and coral closures and Steller sea lion trawl exclusion zones in the Aleutian Islands) have several common features. The MPA's designed for conservation are found in areas with many cold water coral and sponges, which are vulnerable to the impacts of bottom trawling. In the case of the SSL, even though the trawl exclusion zone was intended to reduce fishing mortality on SSL prey, the habitat associated with SSL prey species was also protected.

For MPA's designed to protect habitat and preserve ecosystem functioning, monitoring may be viewed as unnecessary since the main goal is to prevent the disturbance that the re- serve itself is guaranteeing. Without monitoring, though, it is not possible to evaluate if a closure had the intended effect and if it affected other ecosystem functions as well. In the case of the protection of prey species for SSL, the monitoring of prey abundance revealed that the effectiveness of the exclusion zone depended on the extent of movement of fish across the exclusion zone boundary. However, because the exclusion zones reduced fishing mortality of the major SSL prey species, Atka mackerel, and protected their spawning and nest guarding habitat, it might have had a positive effect on the reproductive success of this species (Cooper and McDermott, 2011). A similar effect was observed for the sandeel, where the protected areas ensured continued recruitment while the spillover of the fish from the closed areas poten- tially contributed to the fisheries catch in the open areas. These results may mitigate the short-term impacts of a fishery to local aggregations by protecting habitat critical for spawning or nest guarding.

\section{Fisheries Management MPA's}

Responses to fishery closures depend on a number of factors. The first factor is the depletion level of the stock when closures are implemented. Because biomass within the closures cannot increase on average higher than virgin level (assuming unchanged carrying capacity for the stock), larger increases inside the closures can theoretically occur for heavily fished stocks than for those that are lightly fished. In addition, increased adult mobility will allow for emigration into fished areas and therefore negate the closure effect. Species of moderate mobility 
Table 2.-Characteristics of the six stocks examined here (Georges Bank cod, haddock, yellowtail flounder, southern New England yellowtail flounder, goosefish (combined southern and northern stocks), and Georges Bank sea scallops. The columns give fully recruited preclosure fishing mortality $F_{p c}$, computed as the mean of the fishing mortalities between 1992-1994, the current estimate of $F_{M s y}$, estimated preclosure biomass ( $B_{p e}$ in $\left.t\right)$ in 1994, the current estimate of $B_{M S Y}$, and the ratios of $F_{p c}$ to $F_{M S Y}$ and $B_{p c}$ to $B_{M S Y}$ prior to the closures in 1994. All estimates are from the most recent stock assessments for these stocks (NEFSC, 2010; Legault et al., 2011; Brooks et al., 2012; O'Brien et al., 2012).

\begin{tabular}{lcccrrr}
\hline Stock & F & FMSY & F/FMSY & B & BMSY & B/BMSY \\
\hline GB cod & 1.07 & 0.25 & 4.28 & 18538 & 248048 & 0.13 \\
GB haddock & 0.46 & 0.35 & 1.31 & 20406 & 158000 & 0.13 \\
GB yellowtail & 1.50 & 0.25 & 5.91 & 2823 & 43200 & 0.07 \\
SNE yellostail & 1.72 & 0.24 & 7.20 & 1308 & 7790 & 0.17 \\
Goosefish & 0.29 & 0.37 & 0.78 & 160000 & 129002 & 1.24 \\
GB Scallop & 1.07 & 0.25 & 418 & 5719 & 45838 & 0.12 \\
\hline
\end{tabular}

may increase in abundance if at least a portion of the fish remain within the closure, but the population increase will likely be less than that of stationary species because some migration of individuals from the closures to the fished areas will occur. Finally, if the closures induce an increase in spawning stock biomass, they may also increase recruitment; this is often termed larval spillover (Planes et al., 2009).

The condition where expected recruitment is well below the level that would produce maximum sustainable yield is often referred to as "recruitment overfishing." Increases in recruitment can only be expected if the depletion level and mobility of the stock allow for considerable increases in biomass inside the closures, and recruitment overfishing was occurring prior to the areas being closed. When both of these conditions are met, increased recruitment and reduced fish- ing mortality can result in a large increase in biomass inside the MPA. However, closures can increase fishery yield only when the stock is recruitment overfished (Hart, 2006)

Consistent with these ideas was the response of some of the fish stocks described in this paper. Sea scallop biomass in New England, lobster biomass in Norway, and sea peach abundance in the eastern Bering Sea increased inside the closures because they had been depleted and are not very mobile. On the other hand, Georges Bank Atlantic cod and Bering Sea Pacific cod appeared to show no response to the closures, likely because of higher mobility between open and closed areas. Goosefish showed a modest response to the closures, likely due to low fishing effort and moderate mobility.

Biomass and recruitment of Georges Bank haddock has increased greatly since the closures, due to the combina- tion of its severe depletion level prior to the closures, moderate mobility, and clear evidence of recruitment overfishing. The MPA's may have been particularly important for haddock in the first 5-10 years after the closures. Norwegian sandeel and Aleutian Islands Atka mackerel benefited from the closures presumably because reproductive success was ensured by protecting spawning habitat and larval spillover contributed to recruitment in the fished areas as well.

The response of yellowtail flounder stocks in New England and flatfish and invertebrate species in the eastern Bering Sea to the closures were mixed. It is possible that the closures for yellowtail flounder in New England pushed effort towards the more productive areas and thus may have contributed to the observed declines. Closures in the Bering Sea seemed to be positive for more than half of the flatfish cases examined, but not in all areas. The crab species in the Bering Sea for which these closures were originally designed did not benefit from the closures. In fact, several crab species exhibited declines in abundance. This was most likely due to the fact that directed fishing for these species was not reduced, only bycatch of crabs in the trawl fisheries targeting other species. These closures most likely did not reduce overall fishing mortality

Table 3.-MPA design considerations.

\begin{tabular}{|c|c|c|c|c|}
\hline MPA type & Goal & Species characteristics & Area closure characteristics & MPA management \\
\hline Habitat Conservation MPA & $\begin{array}{l}\text { Habitat preservation to } \\
\text { void/reduce human impact } \\
\text { on habitat }\end{array}$ & $\begin{array}{l}\text { Species associated with certain } \\
\text { habitat types Species remain } \\
\text { within boundaries of MPA }\end{array}$ & $\begin{array}{l}\text { Needs to encompass desired } \\
\text { habitat types (e.g., unique } \\
\text { characteristics which support } \\
\text { high biodiversity or high } \\
\text { recreational value) }\end{array}$ & $\begin{array}{l}\text { Enforcement necessary; easier to } \\
\text { achieve when effort redistribution } \\
\text { effects are not large }\end{array}$ \\
\hline $\begin{array}{l}\text { Fishery Management MPA } \\
\text { (rebuild age structure) }\end{array}$ & $\begin{array}{l}\text { Increase yield through the } \\
\text { growth of larger individuals }\end{array}$ & $\begin{array}{l}\text { Spillover effect of large adult } \\
\text { individuals; small adult } \\
\text { movement }\end{array}$ & $\begin{array}{l}\text { Needs to encompass local } \\
\text { population; rotational closures } \\
\text { can be effective }\end{array}$ & $\begin{array}{l}\text { Enforcement necessary; additional } \\
\text { quota/effort management needed to } \\
\text { prevent overfishing in adjacent open } \\
\text { areas; fishing the line likely }\end{array}$ \\
\hline $\begin{array}{l}\text { Fishery Management MPA } \\
\text { (larval spillover effect) }\end{array}$ & $\begin{array}{l}\text { Enhance recruitment in } \\
\text { exploited areas }\end{array}$ & $\begin{array}{l}\text { Large larval movement; } \\
\text { small adult movement }\end{array}$ & $\begin{array}{l}\text { Needs to encompass local } \\
\text { population, spawning grounds } \\
\text { and/or nursery area }\end{array}$ & Enforcement necessary \\
\hline $\begin{array}{l}\text { Fishery Management MPA } \\
\text { (minimize exploitation rate) }\end{array}$ & $\begin{array}{l}\text { Rebuild stock (recent crash) by } \\
\text { minimizing exploitation rate }\end{array}$ & $\begin{array}{l}\text { Small adult movement } \\
\text { Large larval movement } \\
\text { Spillover effect of adult fish } \\
\text { into open area }\end{array}$ & $\begin{array}{l}\text { Needs to encompass large } \\
\text { enough area to ensure successful } \\
\text { local recruitment. }\end{array}$ & $\begin{array}{l}\text { Enforcement necessary; additional } \\
\text { quota/effort management needed to } \\
\text { prevent overfishing Potential effort } \\
\text { reduction necessary due to smaller } \\
\text { fished area; fishing the line likely }\end{array}$ \\
\hline $\begin{array}{l}\text { Fishery Management MPA } \\
\text { (protect spawning grounds) }\end{array}$ & $\begin{array}{l}\text { Sustainable production, and to } \\
\text { prevent recruitment overfishing }\end{array}$ & $\begin{array}{l}\text { Species well-defined spawning } \\
\text { aggregations and seasons }\end{array}$ & $\begin{array}{l}\text { Spawning grounds can be closed } \\
\text { seasonally or locally and still allow } \\
\text { fishery to occur outside of closed } \\
\text { area/season }\end{array}$ & $\begin{array}{l}\text { Seasonal enforcement necessary; more } \\
\text { challenging to gain fishery support } \\
\text { when there is a roe fishery. }\end{array}$ \\
\hline
\end{tabular}


enough for the crab stocks to increase in abundance.

\section{MPA Design}

\section{Habitat Conservation MPA's}

In this paper we show two approaches to designing MPA's for habitat closures. The first approach was the identification and mapping of vulnerable habitat in the Barents Sea and included a precautionary closure. This was followed by the implementation of better directed closures to protect the most valuable and vulnerable areas based on the knowledge gained with the habitat mapping project. The challenge here is twofold. First, it is necessary to clearly identify "vulnerable areas" and distinguish them from surrounding areas. Because vulnerable habitat often occurs in a large enough percentage of the total habitat to preclude closure of all vulnerable habitat, the second challenge is for managers to implement the closures in a manner which balances the ecological and economic impacts of the closures. This approach can work well if management decisions on closure locations are informed by science and formal risk analyses, rather than by political pressure from user groups.

The second approach discussed is to close areas that have not been previously exploited. This approach enabled MPA's to be implemented for the Aleutian Island coral areas without extensive seafloor mapping. Since these areas had not yet been exploited by the fishery (mainly because bottom conditions precluded the use of typical trawl gear on a practical basis), potential economic loss to the fishery was minimal and the fishing industry was cooperative in establishing these closures. These closures might not have been so well received if the fishing industry or the oil and gas industry would had seen a significant future benefit in exploiting those areas. The success of this approach is based on finding sensitive and ecologically valuable areas that have not been exploited and therefore are easier for the resource users to "give up."

\section{Fisheries Management MPA's}

Another scenario often encountered by managers are spatial closures to address fisheries management concerns. Examples discussed here are the sandeel in the North Sea, the lobster and Atlantic cod in Norway, the groundfish and scallop closures on Georges Bank, the closures in the Eastern Bering Sea for crab bycatch, and the Steller sea lion trawl closures in the Aleutian Islands.

One goal in the design of these closures was to encompass as much of a declining stock as possible, while still allowing a commercial fishery to take place. This is usually a response to a crisis that has to be addressed quickly and may not allow for a careful precautionary approach when designing an MPA.

In many cases, MPA's are based on fishing information and/or survey information regarding areas of species abundance and population decline. As in the examples above, these MPA's often encompass some or all of the preferred fishing grounds. This approach is viable if the protected species have moderate mobility such that population increases in the protected area spill over into fished areas and increase yield, and if the recovery is not hindered by impacts in other stages in the species' life cycle (e.g., reproduction, nursery habitat). For this reason, it is important to understand ontogenetic habitat use and the life history strategy of the species to be protected.

The two main approaches to the design of an MPA (Conservation vs. Fisheries Management) are outlined in Table 3, including the appropriate goals, the characteristics most likely to render a species a candidate for MPA management, the characteristics of the habitat and, finally, the level of MPA management suggested to achieve the desired goals.

\section{MPA Monitoring}

Monitoring the successful achievement of MPA goals can be time-consuming and labor intensive. In the cases presented in this paper, only two MPA's had a dedicated monitoring scheme (the lobster reserves in Norway and the Steller sea lion trawl exclusion zones in Alaska). While many species associated with the MPA's considered here have estimates of abundance available from fishery stock assessments, this information is only available at spatial scales much larger than the MPA - rendering evaluation of the MPA difficult.

As such, the success of spatial management measures such as fishery closures is often difficult to measure. In order to evaluate the success or failure of an MPA as a management tool, it should be stressed that, although data can be expensive to obtain, monitoring is an important part of the feedback loop (Jones et al., 2011). For a relatively sessile species like the Norway lobster, closing a small "test area" to fishing in a place that is easy to monitor can be a first step in developing a monitoring program for an MPA. Stocks, such as Pacific and Atlantic cod, that undergo long migrations and/or have large spatial distributions will probably require large closed areas and will require more resources to monitor effectively. Monitoring adults stock using tools such as tagging programs, will give insight into the effects of movement across the boundaries of areal closures on adult biomass. On the other hand, it may be difficult to distinguish the effects of larval spillover from an MPA from other factors influencing larval survival. Thus, it is essential to include a well-designed monitoring and evaluation program in an MPA management plan.

In addition to research monitoring of the ecosystem it is also essential to establish enforcement monitoring. In many U.S. Federal fisheries in Alaska and Northeast Atlantic, fishing vessels have been equipped with satellite vessel monitoring systems that enable managers to track fishing vessels in real time. This monitoring can ensure compliance around MPA boundaries; however, enforcement can often be more complicated than just tracking presence or absence inside closed areas. Enforcing gear compliance can be 
more challenging and often requires close monitoring of activities, which can be accomplished by an observer program such as the ones used for fisheries in the U.S (Faunce and Barbeaux, 2011) or increasingly effective electronic monitoring programs.

\section{Side Effects of MPA's}

Area closures can have unexpected consequences affecting both stocks and the economics of the fishery. In cases where implementation is not accompanied by an overall reduction in fishing effort, MPA implementation can result in intensified fishing outside the closed areas because the fishable grounds have been reduced. This may result in increased exploitation and reduced biomass outside the closures, potentially offsetting increases within the closures, and may result in localized overfishing if fish migrate outside the closed area and are disproportionately captured at the borders of the MPA. This may have occurred for Atlantic cod in the North Atlantic and yellowfin sole in the Bering Sea. The positive effect of the closures would then be directly correlated to the movement behavior of the protected species and the fishing intensity outside the MPA.

Displacement of fishing effort may also result in undesired bycatch, which occurred when fishing effort displaced by the Bering Sea crab MPA's resulted in an increase in halibut bycatch $(\mathrm{Ab}$ bott and Haynie, 2012). Side effects of MPA's are often difficult to predict so it is important to study potential aspects of closures and incorporate a feedback loop into an adaptive management scheme. Unwanted side effects can be better anticipated by considering fleet dynamics and can be mitigated by changes in the MPA design or other fishery management tools. Most MPA designs should not be considered static but flexible, allowing for continuous improvement through monitoring, evaluating, and adjusting the design and management strategy. Finally, not all side effects may be negative. When the closure to protect vulnerable marine ecosystems (VME's) also includes essential fish habitats, such as coral reefs, it can have an additional benefit for fish species thriving in the VME (Buhl-Mortensen et al., 2010).

\section{Challenges for Northern Region MPA's}

MPA's in northern regions present specific challenges. The remoteness and size of the areas to be managed often hinder the collection of data at the appropriate spatial scale. The large home range of some of the important commercial species makes them questionable candidates for area closures. In addition, many species' life history traits and their habitat requirements during their early life history are often unknown and might be changing with changing environmental conditions such as global warming.

The complex fisheries management systems in these regions make MPA implementation a lengthy process. However, given all of these challenges, the well-established management and enforcement plans in all three regions discussed in this paper also make it possible to track population status through stock assessments and enforce the closures.

The biggest challenge for MPA's in northern areas will be to include sufficient area to encompass vulnerable species' home ranges without excessive monitoring costs or fishery impacts. Quota management and effort allocation may still be the most effective management tools used in these areas, with MPA's supplementing these tools where appropriate.

\section{Conclusions}

MPA's can be effective management tools when the areas are designed with clear goals, the species to be protected are sufficiently concentrated within the closed areas, and the MPA design is based on scientific information rather than simply the path of least resistance to user groups. The most successful fisheries management MPA's were for low mobility species of depleted stock status that stayed within the MPA, such as the North Atlantic scallops, haddock, and Norwegian lobster. The least successful MPA's included species that moved freely across boundaries, such as the Northeast Atlantic and Bering sea cod. Successful MPA's for increasing reproductive success worked well when critical spawning or nursery ground were protected, such as the sandeel and Atka mackerel spawning and nesting areas. Habitat protection MPA's need enough scientific information to identify vulnerable habitat, which often is a costly process.

In recent years, frameworks have been established to assess and evaluate MPA's, and can be useful tools to guide the monitoring process and adjust management plans in a structured manner (Buhl-Mortensen et al., 2017). The MPA's examined in this paper were developed for a wide variety of purposes. While no case studies presented here have shown significant negative impacts of MPA's on either habitat or species to be protected, the observed benefits of these MPA's have been mixed and in some cases there have been unanticipated negative consequences.

Some MPA's were implemented because they were the most attractive means available to achieve conservation or a fisheries management goal, but the net benefits and costs of these MPA's remain unclear.

Conservation MPA's such as the Aleutian Island coral closure are conceptually easy to design and would be easy to implement if there were no conflicting claims on the area by user groups. This is rarely the case, however, and real-world MPA's usually involve economic and political trade-offs. Even defining success for an MPA is not always straightforward, as the goals of the MPA may be complicated and multifaceted. Similarly, monitoring the impacts of MPA's can be very challenging, especially for multispecies mobile stocks that function as part of a complex and dynamic ecosystem with or without an MPA.

In the MPA's examined for those stocks, success was most evident for low-mobility species in small closures and for habitat closures where removing fishing impacts are the primary 
goal of the closure. In light of the increasing attention MPA's have received in recent years with respect to both conservation and fishery management, MPA's should not be regarded as the solution to all problems but merely as one of several tools used for successful fisheries management.

\section{Acknowledgments}

This paper was developed as a collaborative project between the Institute of Marine Research (Bergen, Norway) and three NMFS groups: the Alaska Fisheries Science Center (Seattle, Wash.) the Alaska Regional Office (Anchorage, Alaska), and the Northeast Fisheries Science Center (Woods Hole, Mass.). The authors would like to thank the Institute of Marine Research and the Alaska Fisheries Science Center for funding workshops in Norway and Seattle. We would like to thank Matt Eagleton, Libby Logerwell, and Chris Rooper for their valuable comments. The findings and conclusions in this paper are those of the authors and do not necessarily represent the views of the National Marine Fisheries Service or IMR. References to trade names does not imply endorsement by the National Marine Fisheries Service, NOAA.

\section{Literature Cited}

Abbott, J., and A. Haynie 2012. What are we protecting? Fisher behavior and the unintended consequences of spatial closures as a fishery management tool. Ecol. Appl. 22:762777. (doi: https://doi.org/10.1890/11-1319.1).

Backus, R. H. 1987. Georges Bank. The MIT Press, Cambridge, Mass., 632 p.

Bailey, K. M., P. J. Stabeno, and D. A. Powers. 1997. The role of larval retention and transport features in mortality and potential gene flow of walleye pollock. J. Fish. Biol. 51:135-154. (doi: https://doi. org/10.1111/j.1095-8649.1997.tb06097.x).

Barcelo, C., L. Ciannelli, E. M. Olsen, T. Johannessen, and H. Knutsen. 2016. Eight decades of sampling reveal a contemporary novel fish assemblage in coastal nursery habitats. Glob. Change Biol. 22:1,155-1,167. (doi: https:// doi.org/10.1111/gcb.13047).

Buhl-Mortensen L., and P. Buhl-Mortensen. 2017. Marine litter in the Nordic Seas: distribution composition and abundance. Mar. Poll. Bull. (doi: https://doi.org/10.1016/j. marpolbul.2017.08.048).

P. Buhl-Mortensen, M. Dolan, and G. Gonzales Mirelis. 2015. Habitat mapping as a tool for conservation and sustainable use of marine resources: some perspectives from the MAREANO programme, Nor- way. J. Sea Res. 100:46-61. (doi: https://doi. org/10.1016/j.seares.2014.10.014).

K. E. Ellingsen, P. BuhlMortensen, K. L. Skaar, and G. GonzalezMirelis. 2016. Trawling disturbance on megabenthos and sediment in the Barents Sea: chronic effects on density, diversity, and composition. ICES J. Mar. Sci. 73:98-114. (doi: https://doi.org/10.1093/icesjms/fsv200). I. Galparsoro, T. Vega Fernandez, G. D’Anna, F. Badalamenti, G. Garofalo, K. Johnson, J. Carlström, C. Pipitone, J. Piwowarczyk, M. Rabaut, J. Vanaverbeke, J. van Dalfsen, C. Schipper, V. Vassilopoulou, Y. Issaris, L. van Hoof, E. Pecceu, K. Hostens, L. Knittweis, M. L. Pace, V. Stelzenmüller, V. Todorova, and V. Doncheva. 2017. Maritime ecosystem-based management in practice: lessons learned from the application of a generic spatial planning framework in Europe. Mar. Pol. 75:174-186. (doi: https://doi. org/10.1016/j.marpol.2016.01.024)

Buhl-Mortensen, P., M. Dolan, and L. BuhlMortensen. 2009. Prediction of benthic biotopes on a Norwegian offshore bank using a combination of multivariate analysis and GIS classification. ICES J. Mar. Sci. 66:2,0262,032. (doi: https://doi.org/10.1093/icesjms/ fsp200).

Clapham, P. J., and J. S. Link. 2006. Whales, whaling, and ecosystems in the North Atlantic Ocean. In J. A. Estes, D. P. Demaster, D. F. Doak, T. M. Williams, and R. L. Brownell (Editors), Whales, Whaling, and Ocean Ecosystems, p. 314-323. Univ. Calif. Press.

Cohen, E. B., and M. D. Grosslein. 1987. Production on Georges Bank compared with other shelf ecosystems. In E. B. Cohen and M. D. Grosslein (Editors), Georges Bank. MIT Press, Cambridge, Mass., p. 593.

Comeau, L. A., S. E. Campana, and M. Castonguay. 2002. Automated monitoring of a largescale cod (Gadus morhua) migration in the open sea. Can. J. Fish. Aqua. Sci. 59:1,8451,850. (doi: https://doi.org/10.1139/f02-152).

Cooper, D., and S. McDermott. 2011. Seasonal, small-scale distribution of Atka mackerel in the Aleutian Islands, Alaska, with respect to reproduction. Mar. Coast. Fish. 3:10-20. (doi: https://doi.org/10.1080/19425120.2011.5584 39)

Coyle, K. O. 2005. Zooplankton distribution, abundance and biomass relative to water masses in eastern and central Aleutian Island passes. Fish. Ocean. 14:77-92. (doi: https:// doi.org/10.1111/j.1365-2419.2005.00367.x).

Crowder, L., G. Osherenko, O. R. Young, S. Airame, E. Norse, N. Baron, J. C. Day, F. Douvere, C. N. Ehler, B. S. Halpern, S. J. Langdon, K. L. McLeod, J. C. Ogden, R. E. Peach, A. A. Rosenberg, and J. A. Wilson. 2006. Resolving mismatches in U.S. ocean governance. Science 313:617-618. (doi: https://doi.org/10.1126/science.1129706).

Douvere, F. 2008. The importance of marine spatial planning in advancing ecosystem-based sea use management. Mar. Pol. 32.762-771. (doi: https://doi.org/10.1016/j. marpol.2008.03.021).

FAO. 2011. Fisheries management. Chap. 4, Marine protected areas and fisheries. FAO Tech. Guidel. Resp. Fish. 219, 198 p.

Faunce, C. H., and S. J. Barbeaux. 2011. The frequency and quantity of Alaskan groundfish catcher-vessel landings made with and without an observer. ICES J. Mar. Sci. $68: 1,757-1,763$.

Fenberg, P. B., J. E. Caselle, J. Claudet, M. Clemence, S. D. Gaines, J. A. García-Charton, E. J. Gonçalves, K. Grorud-Colvert, P. Guidetti, S. R. Jenkins, P. J. S. Jones, S. E. Lester, R McAllen, E. Moland, S. Planes, and T. K. Sorensen. 2012. The science of European marine reserves: status, efficacy, and future needs. Mar. Pol. 36:1,012-1,021. (doi: https:// doi.org/10.1016/j.marpol.2012.02.021).

Fenner, D. 2016. Criticism of marine protected areas by fisheries scientists. Mar. Poll. Bull. 108:12-14. (doi: https://doi.org/10.1016/j. marpolbul.2016.05.026).

Fernández-Chacón, A., E. Moland, S. H. Espeland, and E. M. Olsen. 2015. Demographic effects of full versus partial protection from harvesting: inference from an empirical before-after control-impact study on Atlantic cod. J. Appl. Ecol. 52:1,206-1,215. (doi: https://doi.org/10.1111/1365-2664.12477).

Fernandez, L., J. Day, A. Lewis, S. Slegers, B. Kerrigan, D. Breen, D. Cameron, B. Jago, J. Hall, D. Lowe, J. Innes, J. Tanzer, V. Chadwick, L. Thompson, K. Gorman, M. Simmons, B. Barnett, K. Sampson, G. De'ath, B. Mapstone, H. Marsh, H. Possingham, I. Ball, T. Ward, K. Dobbs, J. Aumend, D. Slater, and K. Stapleton. 2005. Establishing representative no-take areas in the Great Barrier Reef: Large-scale implementation of theory on marine protected areas. Conserv. Biol. 19:1,733-1,744.

Fernandez, M., and J. C. Castilla. 2005. Marine conservation in Chile: historical perspective, lessons, and challenges. Conserv. Biol. 19:1,752-1,762. (doi: https://doi. org/10.1111/j.1523-1739.2005.00277.x

Field, J. C., A. E. Punt, R. D. Methot, and C. J. Thomson. 2006. Does MPA mean 'major problem for assessments'? Considering the consequences of place-based management systems. Fish Fish. 7:284-302. (doi: https:// doi.org/10.1111/j.1467-2979.2006.00226.x).

Fogarty, M. J., and S. A. Murawski. 1998 Large-scale disturbance and the structure of marine system: Fishery impacts on Georges Bank. Ecol, Appl. 8:S6-S22. (doi: https://doi. org/10.2307/2641359).

Gaines, S. D., C. White, M. H. Carr, and S. R. Palumbi. 2010. Designing marine reserve networks for both conservation and fisheries management. Proc. Natl. Acad. Sci. U.S.A. 107:18,286-18,293. (doi: https://doi. org/10.1073/pnas.0906473107).

Gleason, M., S. McCreary, M. Miller-Henson, J. Ugoretz, E. Fox, M. Merrifield, W. McClintock, P. Serpa, and K. Hoffman. 2010. Science-based and stakeholder-driven marine protected area network planning: A successful case study from north central California. Ocean Coast. Manage. 53:52-68. (doi: https:// doi.org/10.1016/j.ocecoaman.2009.12.001).

Grafton, R. Q., S. Akter, and T. Kompas. 2011. A policy-enabling framework for the ex-ante evaluation of marine protected areas. Ocean Coast. Manage. 54:478-487. (doi: https://doi. org/10.1016/j.ocecoaman.2011.03.006)

Gray, J. S. 1997. Marine biodiversity: patterns, threats and conservation needs. Biodiversity Conserv. 6:153-175.

2001. Marine diversity: the paradigms in patterns of species richness examined. Scientia Marina 65:41-56. 
Greenville, J., and T. G. Macaulay. 2007. Untangling the benefits of protected areas in fisheries. Mar. Resour. Econ. 22:267-285. (doi: https://doi.org/10.1086/mre.22.3.42629559).

Hansen, G. J. A., N. C. Ban, M. L. Jones, L. Kaufman, H. M. Panes, M. Yasue, and A. C. J. Vincent. 2011. Hindsight in marine protected area selection: A comparison of ecological representation arising from opportunistic and systematic approaches. Biol. Conserv. 144:1,866-1,875. (doi: https://doi. org/10.1016/j.biocon.2011.04.002).

Haring, P., and J. J. Maguire. 2008. The monkfish fishery and its management in the northeastern USA. ICES J. Mar. Sci. 65:1,370-1,379. (doi: https://doi.org/10.1093/icesjms/fsn131)

Hart, D. R. 2006. When do marine reserves increase fishery yield? Can. J. Fish. Aquat. Sci. 63:1,445-1,449. (doi: https://doi.org/10.1139/ f06-071)

and P. J. Rago. 2006. Long-term dynamics of U.S. Atlantic sea scallop Placopecten magellanicus populations. N. Am. J. Fish. Manage. 26:490-501. (doi: https://doi. org/10.1577/M04-116.1).

L. D. Jacobson, and J. Tang. 2013. To split or not to split? Assessment of Georges Bank sea scallops (Placopecten magellanicus) in the presence of marine protected areas. Fish. Res. 144:74-83. (doi: https://doi. org/10.1016/j.fishres.2012.11.004)

Haynie, A. C., and D. F. Layton. 2010. An expected profit model for monetizing fishing location choices. J. Environ. Econ. Manage. 59:165-176. (doi: https://doi.org/10.1016/j. jeem.2009.11.001

Hennemuth, B., and S. Rockwell. 1987. History of fisheries conservation and management. In R. Backus (Editors), Georges Bank, p. 430 446. MIT Press, Cambridge, Mass.

Holland, G. J., S. P. R. Greenstreet, I. M. Gibb, H. M. Fraser, and M. R. Robertson. 2005. Identifying sandeel Ammodytes marinus sediment habitat preferences in the marine environment. Mar. Ecol.-Prog. Ser. 303:269-282. (doi: https://doi.org/10.3354/meps303269).

Hunt, G. L., and B. A. Megrey. 2005. Comparison of the biophiscal and trophic characteristics of the Bering and Barents Seas. ICES J. Mar. Sci. 62:1,245-1,255. (doi: https://doi. org/10.1016/j.icesjms.2005.04.008).

ICES. 2009. Report of the ad hoc ground on Sandeel-II. 19-21 Oct. 2009, Copenhagen, Denmark. ICES Agsan2 Rep. 2009, ICE Advis. Comm., ICES CM 2009\ACOM 51, 53 p. 2012. Report of the ICES Advisory Committee 2012. ICES Advice 2012, Book 6, North Sea, 443 p.

Jones, P. J. S., W. Qiu, and E. De Santo. 2011. Governing marine protected areas-Getting the balance right. Tech. Rep., U.N. Environ. Prog., Nairobi, 105 p.

Katsanevakis, S., V. Stelzenmueller, A. South, T. K. Soerensen, P. J. S. Jones, S. Kerr, F. Badalamenti, C. Anagnostou, P. Breen, G. Chust, G. D’Anna, M. Duijn, T. Filatova, F. Fiorentino, H. Hulsman, K. Johnson, A.P. Karageorgis, I. Kroncke, S. Mirto, C. Pipitone, S. Portelli, W. Qiu, H. Reiss, D. Sakellariou, M. Salomidi, L. van Hoof, V. Vassilopoulou, T. Vega Fernandez, S. Voge, A. Weber, A. Zenetos, and R. ter Hofstede. 2011. Ecosystem-based marine spatial management: Review of concepts, policies, tools, and critical issues. Ocean Coastal Manage.
54:807-820. (doi: https://doi.org/10.1016/j. ocecoaman.2011.09.002)

Kelleher, G. (Editor). 1999. Guidelines for marine protected areas. World Commiss. Prot. Areas, 2nd ed., IUCN, Best Practice Protected Area Guidelines Series No. 3, $107 \mathrm{p}$

Kleiven, A. R., E. M. Olsen, and J. H. Volstad. 2011. Estimating recreational and commercial fishing effort for European lobster Homarus gammarus by strip transect sampling. Mar. Coastal Fish. 3:383-393. (doi: https:// doi.org/10.1080/19425120.2011.638798).

A. Fernández-Chacón, J.-H. Nordahl, E. Moland, S. H. Espeland, H. Knutsen, and E. M. Olsen. 2016. Harvest pressure on coastal Atlantic cod (Gadus morhua) from recreational fishing relative to commercial fishing assessed from tag-recovery data. Plos One 11, e0149595, 14 p. (doi: https://doi. org/10.1371/journal.pone.0149595).

Knutsen, H., P. E. Jorde, C. André, and N Stenseth. 2003. Fine-scaled geographical population structuring in a highly mobile marine species: the Atlantic cod. Mol. Ecol. 12:385-394. (doi: https://doi.org/10 1046/j.1365-294X.2003.01750.x).

Ladd, C., G. L. Hunt, C. W. Mordy, S. A. Salo, and P. J. Stabeno. 2005. Marine environment of the eastern and central Aleutian Islands. Fish. Ocean. 14:22-38. (doi: https://doi. org/10.1111/j.1365-2419.2005.00373.x).

Lauth, R. R. 2011. Results of the 2010 eastern and northern Bering Sea contintental shelf bottom trawl survey of groundfish and invertebrate fauna. U.S. Dep. Commer., NOAA Tech. Memo. NMFS-AFSC-227, $256 \mathrm{p}$.

Legault, C. M., L. Alade, and H. H. Stone. 2011. Stock assessment of Georges Bank yellowtail flounder for 2011. Transboundary resources assessment committee. Ref. Doc 2011/01, $111 \mathrm{p}$

Lester, S. E., B. S. Halpern, K. Grorud-Colvert, J. Lubchenco, B. I. Ruttenberg, S. D. Gaines, S. Airame, and R. R. Warner. 2009. Biological effects within no-take marine reserves: a global synthesis. Mar. Ecol.-Prog. Ser. 384:33-46. (doi: https://doi.org/10.3354/ meps08029).

Logerwell, E. A., K. Aydin, S. Barbeaux, E. Brown, M. E. Conners, S. Lowe, J. W. Orr, I. Ortiz, R. Reuter, and P. Spencer. 2005. Geographic patterns in the demersal ichthyofauna of the Aleutian Islands. Fish. Ocean. 14:93-112. (doi: https://doi.org/10.1111/j. 1365-2419.2005.00366.x).

Loughlin, T. R. 1998. The Steller sea lion: a declining species. Biosphere Conserv. 1:91-98. (doi: http://doi.org/10.20798/biospherecons 1.2_91).

Lubchenko, J., S. R. Paumbi, S. D. Gaines, and S. Andelman. 2003. Plugging a hole in the ocean: the emerging science of marine reserves. Ecol. Appl. 13:3-7. (doi: https://doi. org/ 10.1890/1051-0761(2003)013[0003:PAH ITO]2.0.CO;2).

Martell, S. J. D., T. E. Essington, B. Lessard, J. F. Kitchell, C. J. Walters, and C. H. Boggs. 2005. Interactions of productivity, predation risk, and fishing effort in the efficacy of marine protected areas for the central Pacific. Can. J. Fish. Aquatic Sci. 62:1,320-1,336. (doi: https://doi.org/10.1139/f05-114).

McDermott, S. F., L.W. Fritz, and V. Haist. 2005. Estimating movement and abundance of Atka mackerel (Pleurogrammus monopterygius) with tag-release-recapture data.
Fish. Ocean. 14:113-130. (doi: https://doi org/10.1111/j.1365-2419.2005.00380.x).

V. Haist, and K. M. Rand. 2015.

Evaluating the efficacy of trawl exclusion zones by estimating local Atka mackerel abundance and movement patterns in the central and eastern Aleutian Islands. Mar. Coastal Fish., Dyn., Manage., Eco. Sci. 8:334-349. (doi: https://doi.org/10.1080/19425120.2015. 1135218).

Meld, S. 2011. Oppdatering av forvaltningsplanen for det marine miljø i Barentshavet og havområdene utenfor Lofoten (Revised Barents Sea management plan). (Ed. M. o. Environment), Oslo.

Moland, E., E. M. Olsen, K. Andvord, J. A. Knutsen, and N. C. Stenseth. 2011. Home range of European lobster (Homarus gamma$r u s$ ) in a marine reserve: implications for future reserve design. Can. J. Fish. Aquat. Sci. 68:1,197-1,210. (doi: https://doi.org/10.1139/ f2011-053)

, H. Knutsen, P. Garrigou, S. H. Espeland, A. R. Kleiven, C. André, and J. A. Knutsen. 2013. Lobster and cod benefit from small-scale northern marine protected areas: inference from an empirical before-after control-impact study. Proc. Roy. Soc. B-Biol Sci 280:20122679. (doi: https:// doi.org/10.1098/rspb.2012.2679).

Mordy, C. W., P. J. Stabeno, C. Ladd, S. Zeeman, D. P. Wisegarver, S. A. Salo, and G. L. Hunt. 2005. Nutrients and primary production along the eastern Aleutian Island Archipelago. Fish. Ocean. 14:55-76. (doi: https:// doi.org/10.1111/j.1365-2419.2005.00364.x).

Mortensen, P. B., L. Buhl-Mortensen, D. C. Gordon Jr., G. B. J. Fader, D. L. McKeown, and D. G. Fenton. 2005. Effects of fisheries on deep-water gorgonian corals in the Northeas Channel, Nova Scotia (Canada). Am. Fish. Soc. Symp. 41:369-382.

2006. Distribution of deep water corals in Atlantic Canada. Proc. 10th Int. Coral Reef Symp., Okinawa, p. 1832-1848.

Murawski, S. A., R. Brown, H. L. Lai, P. J. Rago, and L. Hendrickson. 2000. Large-scale closed areas as a fishery-management tool in temperate marine systems: The Georges Bank experience. Bull. Mar. Sci. 66:775-798

NEFSC. 2010. 50th Northeast Regional Stock Assessment Workshop (50th SAW). Assessment Report. U.S. Dep. Commer., NOAA, NEFSC Ref. Doc. 10-09, 57 p.

NMFS. 2001. Alaska groundfish fisheries: draf programmatic supplemental environmental impact statement. Juneau, 3,000 p.

NPFMC. 2011a. Stock assessment and fishery evaluation report for the king and Tanner crab fisheries of the Bering Sea and Aleutian Islands regions. N. Pac. Fish. Manage. Council, 222 p. (Online at https://www.npfmc.org/wpcontent/PDFdocuments/fmp/CrabFMPOct11. pdf).

2011b. Stock assessment and fishery evaluation report for the groundfish resources of the Bering Sea/Aleutian Islands regions. N. Pac. Fish. Manage. Council, 1,300 p. (Online at https://www.afsc.noaa gov//refm/stocks/2011_assessments.htm).

2016. Stock assessment and evaluation report for the groundfish resources of the Bering Sea/Aleutians regions: Introduction. N. Pac. Fish. Manage. Council, 52 p. 
(Online at https://www.afsc.noaa.gov/REFM/ Docs/2015/BSAIintro.pdf).

NRC. 1996. The Bering Sea Ecosystem: Report of the Committee on the Bering Sea Ecosystem. Natl. Acad. Press, Wash., D.C., 307 p. (doi: https://doi.org/10.17226/5039).

Olsen, E., and E. Moland. 2011. Fitness landscape of Atlantic cod shaped by harvest selection and natural selection. Evol. Ecol. 25:695-710. (doi: https://doi.org/10.1007/ s10682-010-9427-9)

H. Gjøsæter, I. Røttingen, A. Dommasnes, P. Fossum, and P. Sandberg. 2007. The Norwegian ecosystem-based management plan for the Barents Sea. ICES J. Mar. Sci. 64:599-602. (doi: https://doi. org/10.1093/icesjms/fsm005)

S. Aanes, S. Mehl, J. C. Holst, A. Aglen, and H. Gjøsæter. 2010. Cod, haddock, saithe, herring, and capelin in the Barents Sea and adjacent waters: a review of the biological value of the area. ICES J. Mar. Sci. 67:87-101. (doi: https://doi.org/10.1093/ icesjms/fsp229)

S. Holen, A. H. Hoel, L. BuhlMortensen, and I. Røttingen. 2016. How integrated ocean governance in the Barents Sea was created by a drive for increased oil production. Mar. Pol. 71:293-300. (doi: https:// doi.org/10.1016/j.marpol.2015.12.005).

Oil Spill Prevention, Administration and Response (OSPAR). 2000. Quality Status Report 2000, Region II-Greater North Sea. OSPAR Commiss. Prot. Mar. Environ. North-East Atl., Lond., 136 p. (Online at https:/qsr2010.ospar.org/media/assessments/ QSR_2000_Region_II.pdf)

Ottersen, G., E. Olsen, G. I. van der Meeren, A. Dommasnes, and H. Loeng. 2011. The Norwegian plan for integrated ecosystembased management of the marine environment in the Norwegian Sea. Mar. Pol. 35:389-398. (doi: https://doi.org/10.1016/j. marpol.2010.10.017).

Overholtz, W. J. 2002. The Gulf of MaineGeorges Bank Atlantic herring (Clupea harengus): spatial pattern analysis of the collapse and recovery of a large marine fish complex. Fish. Res. 57:237-254. (doi: https:// doi.org/10.1016/S0165-7836(01)00359-9)

Pettersen, A. R., E. Moland, E. M. Olsen, and J. A. Knutsen. 2009. Lobster reserves in coastal Norway: the process towards establishment. In E. Dahl, E. Moksness, and J. Støttrup (Editors), Integrated coastal zone management, $\mathrm{p}$. 178-188. Wiley-Blackwell, N.J.

Planes, S., G. P. Jones, and S. R. Thorrold. 2009. Larval dispersal connects fish populations in a network of marine protected areas. Proc. Natl. Acad. Sci. 106:5,693-5,697. (doi: https://doi.org/10.1073/pnas.0808007106)

Rand, K. M., and S. A. Lowe. 2011. Defining essential fish habitat for Atka mackerel with respect to feeding within and adjacent to Aleutian Islands trawl exclusion zones. Mar. Coast. Fish. Dynamics Manage. Ecosyst. 3:21-31. (doi: https://doi.org/10.1080/15427 951.2010.558402).
Rice, J., and K. Houston. 2011. Representativity and networks of Marine Protected Areas. Aquat. Conserv: Mar. Freshw. Ecosyst. 21:649-657. (doi: https://doi.org/10.1002/ aqc.1232).

E. Moksness, C. Attwood, S. K. Brown, G. Dahle, K. M. Gjerde, E. S. Grefsrud, R. Kenchington, A. R. Kleiven, P. McConney, M. A. K. Ngoile, T. F. Naesje, E. Olsen, E. M. Olsen, J. Sanders, C. Sharma, O. Vestergaard, and L. Westlund. 2012. The role of MPA's in reconciling fisheries management with conservation of biological diversity. Ocean Coast. Manage. 69:217-230. (doi: https://doi.org/ https://doi.org/10.1016/j. ocecoaman.2012.08.001)

Roberts, C. M., J. P. Hawkins, and F. R. Gell. 2005. The role of marine reserves in achieving sustainable fisheries. Philos. Trans. R Soc. Lond. B Biol. Sci. 360:123-132. (doi: https://doi.org/10.1098/rstb.2004.1578)

Rogers, L. A., E. M. Olsen, H. Knutsen, and N. C. Stenseth. 2014. Habitat effects on population connectivity in a coastal seascape. Mar Ecol. Prog. Ser. 511:153-163. (doi: https:// doi.org/10.3354/meps10944).

Rohde, K. 1992. Latitudinal gradients in species diversity: the search for the primary cause. Oikos 65:514-527. (doi: https://doi. org/10.2307/3545569).

Russ, G. R. 2002. Yet another review of marine reserves as reef fishery management tools. In P. S. Sale (Editor), Coral Reef Fishes: Dynamics and diversity in a complex ecosystem, p. 421-443, Elsevier Sci. (doi: https://doi. org/10.1016/B978-012615185-5/50024-4)

Sanchirico, J. N., U. Malvadkar, A. Hastings, and J. E. Wilen. 2006. When are no-take zones an economically optimal fishery management strategy? Ecol. Appl. 16:1,643-1,659. (doi: https://doi.org/10.1890/ 1051-0761(2006)016[1643:WANZAE]2.0. $\mathrm{CO} ; 2)$.

Shimada, A. M., and D. K. Kimura. 1994. Seasonal movements of Pacific cod, Gadus macrocephalus, in the Eastern Bering Sea and adjacent waters based on tag-recapture data. Fish. Bull. 92:800-816.

Sinclair, E. H., and T. K. Zeppelin. 2002. Seasonal and spatial differences in diet int the western stock of Steller sea lions (Eumetopias jubatus). J. Mammal. 83:973-990. (doi: https://doi.org/10.1644/ 1545-1542(2002)083<0973:SASDID >2.0. $\mathrm{CO} ; 2)$

Smith, M. D., and J. E. Wilen. 2003. Economic impacts of marine reserves: the importance of spatial behavior. J. Environ. Econ. Manage. 46:183-206. (doi: https://doi.org/10.1016/ S0095-0696(03)00024-X).

Sorensen, T. K., and L. N. Thomsen. 2009. A comparison of frameworks and objectives for implementation of marine protected areas in Northern Europe and in Southeast Asia. Aquat. Ecosyst. Health Manage. 12:258-263. (doi: https://doi. org/10.1080/14634980903140323).

Stelzenmüller, V., P. Breen, T. Stamford, F. Thomsen, F. Badalamenti, Á. Borja, L.
Buhl-Mortensen, J. Carlstöm, G. D’Anna N. Dankers, S. Degraer, M. Dujin, F. Fiorentino, I. Galparsoro, S. Giakoumi, M. Gristina K. Johnson, P. J .S. Jones, S. Katsanevakis, L. Knittweis, Z. Kyriazi, C. Pipitone, J. Piwowarczyk, M. Rabaut, T. K. Sørensen, J. van Dalfsen, V. Vassilopoulou, T. Vega Fernández, M. Vincx, S. Vöge, A. Weber, N. Wijkmark, R. Jak, W. Qiu, and R. ter Hofstede. 2013. Monitoring and evaluation of spatially managed areas: A generic framework for implementation of ecosystem based marine management and its application. Mar. Pol 37:149-164. (doi: https://doi.org/10.1016/j. marpol.2012.04.012)

Stewart-Oaten, A., W. W. Murdoch, and K. R. Parker. 1986. Environmental impact assessment: "pseudoreplication" in time? Ecology 67:929-940. (doi: https://doi.org/10.2307/ 1939815).

Sundby, S., and O. Nakken. 2008. Spatial shifts in spawning habitats of Arcto-Norwegian cod related to multidecadal climate oscillations and climate change. ICES J. Mar. Sci. 65:953962. (doi: https://doi.org/10.1093/icesjms/ fsn085).

Thorpe, A., M. Bavinck, and S. Coulthard. 2011. Tracking the debate around marine protected areas: key issues and the BEG framework Environ. Manage. 47:546-563. (doi: https:// doi.org/10.1007/s00267-011-9632-5).

Trexler, J. C., and J. Travis. 2000. Can marine protected areas restore and conserve stock attributes of reef fishes? Bull. Mar. Sci. $66: 853-873$

United Nations (U.N.). 2002. Plan of implementation of the world summit on sustainable development (Johannesburg Summit), $62 \mathrm{p}$. (Online at http://www.un.org/esa/sustdev/ documents/WSSD_POI_PD/English/WSSD_ PlanImpl.pdf)

Villegas-Ríos, D., E. Moland, and E. M. Olsen. 2017. Potential of contemporary evolution to erode fishery benefits from marine reserves. Fish Fish. 18:571-577. (doi: https://doi. org/10.1111/faf.12188).

Witherell, D., and D. Woodby. 2005. Application of marine protected areas for stustainable production and marine biodiversity off Alaska. Mar. Fish. Rev. 67:1-27.

Worm, B. E. B. Barbier, N. Beaumont, E Duffy, C. Folke, B. S. Halpern, J. B. C. Jackson, H. K. Lotze, F. Micheli, S. R. Palumbi, E. Sala, K. A. Selkoe, J. J. Stachowicz, and R. Watson. 2006. Impacts of biodiversity loss on ocean ecosystem services. Science 314:787-790. (doi: https://doi.org/10.1126/ science.1132294)

Wright, P. J. 1996. Is there a conflict between sandeel fisheries and seabirds? A case study at Shetland. In S. P. R. Greenstreet and M. L. Tasker (Editors), Aquatic predators and their prey, p. 154-165. Blackwell Science, Oxford

Zador, S. G. (Editor). 2014. Ecosystem considerations for the North Pacific groundfish stock assessment and fishery evaluation report. U.S. Dep. Commer., NOAA, NMFS, AFSC, Seattle, Wash., 264 p. 